\title{
12. CENOZOIC STRATIGRAPHY AND PALEOCEANOGRAPHY OF BISERIAL PLANKTONIC FORAMINIFERS, ONTONG JAVA PLATEAU ${ }^{1}$
}

\author{
Johanna M. Resig²
}

\begin{abstract}
The Ontong Java Plateau in the western equatorial Pacific contains a deposition record of biserial planktonic foraminifers concentrated in the Paleogene, in which frequencies up to $67 \%$ of the planktonic foraminifers are reported, and in the late Neogene, in which a maximum frequency of $48 \%$ is reported. Biserial planktonic foraminifers are rare or absent in the latest Oligocene and early Miocene, an interval characterized by warm bottom water and low temperature gradients. These conditions supported a surface assemblage rather than the biserial planktonic foraminifers, whose Neogene species inhabited the oxygen minimum at intermediate depths in the upper water column.

Biserial planktonic foraminifers tend to be of high frequency during high sea stands and low frequency during low sea level, presumably in response to the strengthening or weakening of the oxygen minimum. Species extinction and evolution events occur during low sea stands in the Neogene and sometimes correspond to strong reflection horizons of the plateau's seismic stratigraphy.

The biserial species are useful biostratigraphic indexes in the plateau section. The last occurrence (LO) of Streptochilus martini corresponds with the Eocene/Oligocene boundary; S. subglobigerum without Neogloboquadrina acostaensis indicates Zone N15; $S$. latum occurs from the middle of Zone N16 to near the top of Zone N17; S. globigerum ranges from near the top of Zone N17 to the middle of Zone N19/N20; and the $S$. globulosum continuous range begins just before the first left-to-right coiling change of Pulleniatina, but the species becomes rare in the Pleistocene section.
\end{abstract}

\section{INTRODUCTION}

\section{Intent}

This research centers on the distribution of biserial planktonic foraminifers of the genera Streptochilus and Chiloguembelina in the sedimentary section of the Ontong Java Plateau for the following reasons:

1. Evidence from stable isotopes suggests that biserial planktonic foraminifers occupied the oxygen-minimum level of the upper water column (Boersma et al., 1979, 1987; Boersma and Premoli Silva, 1983, 1989; Resig and Kroopnick, 1983; Lauritzen, 1987). They have provided useful information pertinent to the structure of the Atlantic water column during the Paleogene (Boersma et al., 1987; Boersma and Premoli Silva, 1989) but are virtually unstudied relative to Neogene paleoceanography.

2. The thick carbonate section of the Ontong Java Plateau contains a well-preserved record of varying abundances of biserial planktonic foraminifers as well as species turnovers (J. Resig, shipboard observ.), which may relate to sea-level fluctuations and accompanying changes in water mass structure (Resig, 1989).

3. Continuous coring and good stratigraphic control in the Ontong Java Plateau section (Kroenke, Berger, Janecek, et al., 1991) might further define the stratigraphic ranges of the various species and increase stratigraphic resolution within the existing zonal schemes (Blow, 1969; Berggren, 1969; Berggren and Miller, 1988).

\section{METHODS}

Samples were selected from the two shallowest locations of Ocean Drilling Program (ODP) Leg 130 (Fig. 1), Site 806 in $2521 \mathrm{~m}$ water depth at $0^{\circ} 19.11^{\prime} \mathrm{N}, 159^{\circ} 21.68^{\prime} \mathrm{E}$, and Site 807 in $2804 \mathrm{~m}$ water depth at $3^{\circ} 36.42^{\prime} \mathrm{N}, 156^{\circ} 37.49^{\prime} \mathrm{E}$, where foraminiferal tests are well preserved and the carbonate stratigraphy is mostly continuous. At Site

\footnotetext{
'Berger, W.H., Kroenke, L.W., Mayer, L.A., et al., 1993. Proc. ODP. Sci. Results, 130: College Station, TX (Ocean Drilling Program).

${ }^{2}$ Department of Geology and Geophysics, School of Ocean and Earth Science and Technology, University of Hawaii, 2525 Correa Road, Honolulu, HI 96822, U.S.A.
}

806 , the interval from the Pleistocene to the base of the Miocene ( 24 Ma) was sampled, and at Site 807 the interval from the Pleistocene through the upper middle Eocene ( $42 \mathrm{Ma})$. In both boreholes, two $10-\mathrm{cm}^{3}$ samples per core, generally taken in Sections 2 and 4, plus some additional core-catcher samples of variable volume were examined, providing resolution of about 83,000 to $500,000 \mathrm{yr}$, depending upon the sedimentation rate. The sectional samples were dried and weighed before being processed so as to record actual foraminiferal abundances. Both the shipboard core-catcher samples and the sectional samples were sieved through a screen with 0.063 -mm openings. The sectional sand fractions were dried in an oven at $40^{\circ} \mathrm{C}$, whereas the shipboard sand fractions were dried at medium heat on a hot plate to speed the identification of stratigraphic markers.

The sand fractions were divided by means of an Otto microsplitter into aliquots containing between approximately 500 and 1000 specimens, which were tallied according to the following categories: benthic foraminifers, Streptochilus or Chiloguembelina, and other planktonic foraminifers. The percentage of benthic foraminifers was used to evaluate the extent to which selective solution affected the constituents, as benthic tests, which are the product of deep-water secretion, are generally thicker walled and less porous than planktonic tests, rendering them relatively more resistant.

The small size of the biserial planktonic foraminifers makes their species identification difficult; however, diagnostic features such as shape and chamber globosity, as well as faint impressions of surface texture, are all visible under the light microscope at magnifications of $50 \times$ or more. Thus, downcore species distributions were determined through light microscopy, but the distributions were confirmed by scanning electron microscope (SEM) photomicrographs in the Paleogene part of the section.

The stratigraphic section in the two drill holes was calibrated with the time scale of Berggren et al. (1985a, 1985b) using first and last appearance datums (FADs and LADs) of planktonic foraminifers and calcareous nannofossils (site reports in Kroenke, Berger, Janecek, et al., 1991) and extrapolating between data points by assuming uniform sedimentation rates. The Eocene/Oligocene boundary was adjusted two cores higher than that reported in the shipboard results because of the upward extent of Hantkenina spines and the presence of Pseudohastigerina in the absence of Cassigerinella chipolensis. The 


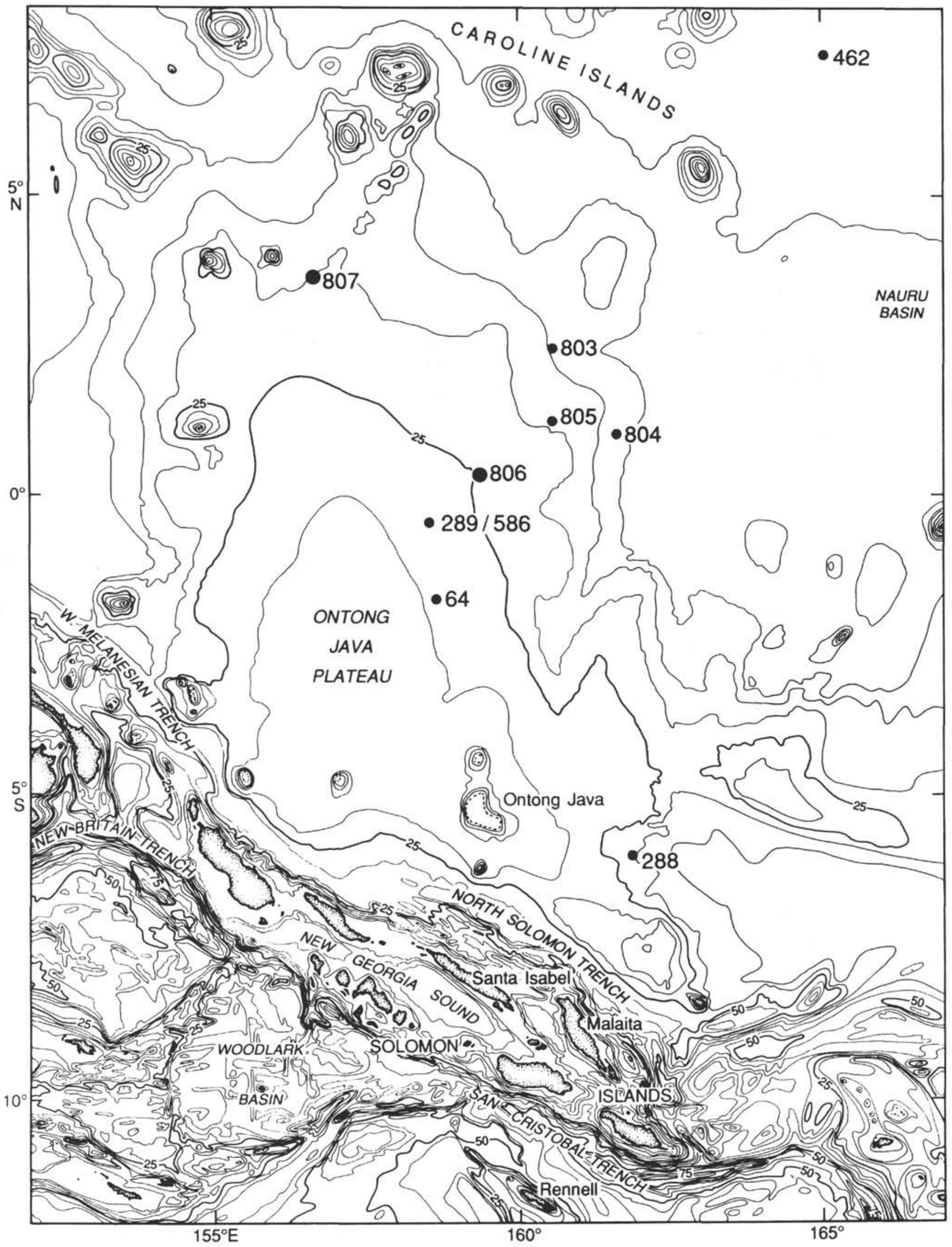

Figure 1. Location of study Sites 806 and 807 in relation to other DSDP and ODP sites on the Ontong Java Plateau. 
analysis was ended in the late Eocene section at Site 807 (about 42 Ma). Below that level, the section had abundant limestone and chert, which hindered recovery and did not allow extraction of individual specimens from the matrix and accurate foraminiferal counts. Numerous unconformities were also recorded in the early Paleogene limestone. Only one unconformity encompassing the span from 28.2 to $30 \mathrm{Ma}$ of the upper Oligocene at Site 807 occurred in the stratigraphic sections analyzed. This unconformity corresponds to a drop in sea level (Haq et al., 1987) and an increase in bottom water $\delta^{18} \mathrm{O}$ (Miller et al., 1987) that may have generated increased current activity around the plateau. Tectonic activity also may have played a role in generating this unconformity (Kroenke et al., this volume).

\section{Environmental Aspects of the Study Area}

Characteristics of the Ontong Java Plateau that most affect the microfossils are its latitudinal position relative to productivity gradients, particularly the equatorial band of upwelling, and the depth of deposition relative to carbonate compensation depth and lysocline levels. Paleomagnetic evidence suggests that the $40-\mathrm{km}$-thick basalt crust forming the plateau's basement erupted at about $33^{\circ} \mathrm{S}$ and that the plateau moved northward with the Pacific Plate and occupied tropical latitudes throughout its Cenozoic history (Hammond et al., 1975). On the basis of the rate of Pacific Plate motion, Site 806 crossed the equator in early Pleistocene time and Site 807 in the early middle Miocene. Preliminary research on benthic foraminiferal species and frequency of total benthic specimens in the 1-km-thick carbonate deposits overlying basement suggests continuous lower bathyal environments and a pelagic depositional regime that kept pace with subsidence (Kroenke, Berger, Janecek, et al., 1991).

\section{RESULTS}

Plots of the downhole analytical data for biserial planktonic foraminifers are shown in Figure 2 relative to the sea-level curve of Haq et al. (1987) and some pertinent benthic and planktonic foraminiferal data of other researchers (Keller, 1985; Miller et al., 1987). Three basic patterns in the distribution of biserial species emerge that require explanation in terms of paleoceanography: (1) the Paleogene and Neogene clustered occurrences, (2) the fluctuating relative abundance of specimens within the two clusters, and (3) the species turnovers.

\section{Paleogene and Neogene Clusters}

A stratigraphic gap roughly $17-\mathrm{m} . y$. long exists between the LO of Paleogene biserial planktonic foraminifers and the first abundant occurrence of the Neogene species at Site 807. Beckmann (1957) reported the highest occurrence of Chiloguembelina cubensis in the Globorotalia opima opima Zone of Trinidad, and Berggren et al. (1985b) placed its LO at the top of Subzone P21a in mid-Chron 10, at $30 \mathrm{Ma}$. However, Hornibrook (1990) extended its upper range into the late Oligocene (middle Chattian) of New Zealand and the basal Miocene of Chatham Island (limestone lens occurrence). The results from Leg 130 support the New Zealand data. Leckie et al. (this volume) record its highest occurrence in Zone P22 of Hole 803D, near the Chron C7/C6C boundary, about 25.3-25.5 Ma. In Hole 807A, the species last occurs in Zone P22 at about 27.6 Ma.

C. cubensis has been placed in the genus Streptochilus by Poore and Gosnell (1985), who noted an internal plate connecting the foramina of all but the final one or two chambers of the test, which also tends to have an aperture that is low and fairly symmetrical (although higher apertural arches are reported elsewhere). The parallel ridges of the pustules comprising the surface sculpture of $C$. cubensis are reminiscent of the texture of some species of Heterohelix. The traits of three genera are combined in this species, and its taxonomic affinity needs further investigation. No intermediate forms have been found to place $C$. cubensis in the direct lineage of the
Neogene species, although stratigraphic considerations suggest it is a possible ancestor. Hornibrook (1990) reported S. pristinum and $C$. cubensis coeval in late Oligocene (middle Chattian) strata of New Zealand, whereas they do not occur together at low-latitude Site 807. The evolution of $S$. pristinum must have occurred before the middle late Oligocene, either from $C$. cubensis $(=S$. cubensis) or from an as yet undiscovered or unrecognized ancestral link to Eocene Streptochilus. The early appearance of S. pristinum in New Zealand suggests that this evolution may have taken place in mid-latitudes rather than in the tropics.

Streptochilus pristinum, the oldest Neogene biserial planktonic, is present sporadically at Sites 806 and 807 beginning about $24 \mathrm{Ma}$, the base of the lower Miocene. The Neogene group does not become prominent until about $10 \mathrm{Ma}$ (late Miocene).

The separation of these two clusters of abundant biserial planktonic foraminifers cannot be attributed to dissolution or poor preservation of tests because the interval of separation contains abundant specimens of other large and small planktonic species and, with few exceptions, benthic species compose only $3 \%$ or less of these pelagic assemblages, typical of good preservation. Kennett et al. (1985) cite additional evidence for the good preservation of lower Miocene (22 $\mathrm{Ma})$ and middle Miocene (16 Ma) planktonic assemblages in the western equatorial Pacific that are comparable with the assemblages found at Sites 806 and 807 (Kroenke, Berger, Janecek, et al., 1991, "Site 806" and "Site 807" chapters).

Isotope signatures of benthic foraminifers (Miller et al., 1987) show a relationship to the clusters (Fig. 2) that suggests paleoceanographic control. The latest Oligocene to early middle Miocene section mostly lacking biserial planktonic foraminifers was deposited at a time when benthic $\delta^{18} \mathrm{O}$ values were low, indicating relatively warm bottom waters. At this time equatorial surface water flowed sluggishly westward into the Indian Ocean, the Equatorial Undercurrent had not yet developed, and both latitudinal and vertical thermal gradients were reduced, which would tend to depress the thermocline (Kennett et al., 1985) and restrict or eliminate the habitat occupied by the Neogene biserial planktonic foraminifers. High benthic $\delta^{18} \mathrm{O}$ beginning in the late middle Miocene, coincident with the major formation of the Antarctic ice sheet (Shackleton and Kennett, 1975), signaled increased thermal gradients accompanied by a shallower thermocline (Kennett et al., 1985) and increased habitats available for intermediate-dwelling planktonic foraminifers (Keller, 1985), including the Neogene oxygen-minimum biserial planktonic foraminifers. The late Eocene to late Oligocene cluster of biserial planktonic foraminifers also occurred during a time of increasing benthic $\delta^{18} \mathrm{O}$ (Fig. 2), but cooler surface waters and a decreasing vertical thermal gradient (Boersma et al., 1987). In contrast to the intermediate-dwelling Neogene biserial species, various species in this interval, including Chiloguembelina cubensis, register near surface isotopic temperatures and relatively high $\delta^{13} \mathrm{C}$ (Poore and Matthews, 1984; Keigwin and Corliss, 1986; Boersma et al., 1987; Boersma and Premoli Silva, 1989). According to Boersma et al. (1987) and Boersma and Premoli Silva (1989), low interplanktonic $\delta^{13} \mathrm{C}$ gradients and relatively high $\delta^{13} \mathrm{C}$ values in the mesopelagic habitat during this interval imply that $\mathrm{cool}$, intermediate waters became ventilated, and low oxygen water shoaled to a position overlying the thermocline. These authors present isotopic and distribution evidence to support the reliability of isotopic measurements on these small biserial species, in view of the size dependence established for some other planktonic foraminifers, and their association with low oxygen water. Shallow, warm, low oxygen water had previously characterized the habitat of biserial planktonic foraminifers in Cretaceous epicontinental seas.

The geographic distribution of biserial planktonic foraminifers has changed through time. In the Cretaceous, they occurred worldwide (Masters, 1977) and were particularly well represented in epicontinental seas (e.g., Eicher and Worstell, 1970; Leckie, 1987). Their Paleogene distribution also was cosmopolitan (Loeblich and Tappan, 1987) but exhibited shifts in latitude in response to paleoceangraphic 


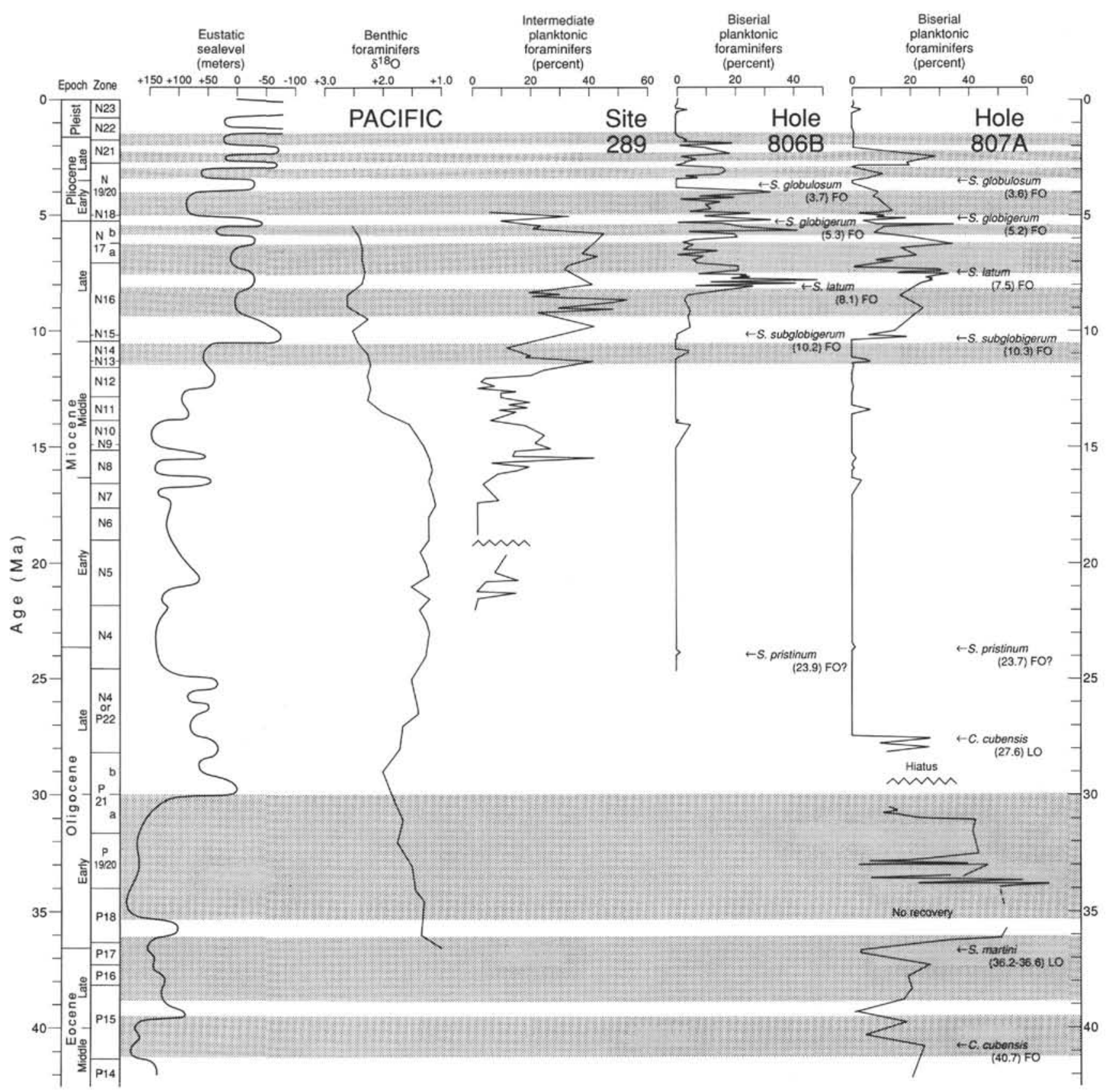

Figure 2. Stratigraphic distribution of biserial planktonic foraminifers in Holes 806B, 807A, and 807C relative to the eustatic sea-level curve (Haq et al., $1987), \delta^{18} \mathrm{O}$ of benthic foraminifers (Miller et al., 1987), and the distribution of intermediate-dwelling planktonic foraminifers (Keller, 1985). Time scale follows Berggren et al. (1985a, 1985b). Shading = relatively high sea levels for sections where biserials are abundant.

conditions (Boersma and Premoli Silva, 1983, 1989; Boersma et al., 1987). In contrast, their Neogene distribution is concentrated in the tropical Indo-Pacific (Resig and Kroopnick, 1983, tables 1-3), with only a few reported occurrences in the central and eastern tropical Pacific, the Caribbean, the Gulf of Mexico, and the Atlantic (Thomas, 1987; Boersma and Premoli Silva, 1989). Mid-Cenozoic biogeographic change involving closure of the Tethys between the Indian and Atlantic oceans, as well as the development of distinct latitudinal belts of planktonic assemblages (cf. Kennett, 1982), have effected this distribution. The localization of oxygen minima of the upper water column caused by increased oxygenation of oceanic waters during the Cenozoic probably played a significant role in the restricted distribution of the biserial planktonic foraminifers (Boersma and Premoli Silva, 1989).

\section{Fluctuating Relative Abundance}

Because the pelagic assemblages are generally well preserved, the relative percentages of the biserial planktonic species reflect actual abundances for the most part (Tables 1-3). The distribution plots on Figure 2 show sample groupings of high frequencies of biserial species (maximum $67 \%$ in the Paleogene and $48 \%$ in the Neogene), separated by relatively low frequencies in curves that are closely similar between the sites where data is available for the Neogene part of the section. This Neogene frequency distribution of biserial species also is similar to that of the Eauripik Rise section to the west (Resig, 1989, figs. 3 and 4), indicating a broad regional pattern of Streptochilus contribution to the sediments. Frequencies of lower magnitude 
that yield roughly similar curves are recorded for the Ninetyeast Ridge in the Indian Ocean (Resig, 1989, fig. 3), suggesting global oceanographic control such as those accompanying changes in sea level.

The fluctuations in frequency of Paleogene biserial planktonic foraminifers show a direct relationship to the sea-level curve (Fig. 2). Highest frequencies occur in conjunction with the long, high sea-level stand during the early Oligocene from about 31 to $35 \mathrm{Ma}$. Boersma and Premoli Silva (1989) have reported high abundances of Chiloguembelina in the Atlantic during this interval, with a maximum of about $25 \%$ in the low latitudes and about $37 \%$ in the high northern latitudes. High frequencies in the mid to late Eocene section of Site 807 also correspond with high sea stands, and low frequencies conversely correspond with lower sea levels. Similar trends occur in the Atlantic distribution of biserials. This concurrence of biserial planktonic foraminifers and high sea stands reflects Fisher and Arthur's (1977) association of an expanded and intensified oxygen-minimum layer with transgressive sequences, higher temperatures, lower initial oxygen content, and diminished ocean circulation.

The hiatus in the Site 807 section, encompassing the interval from 28 to $30.5 \mathrm{Ma}$, corresponds to a drop in sea level and a decrease in bottom-water temperature that may coincide with the initial opening of the Drake Passage (Barker and Burrell, 1977), although major circulation changes brought about by the isolation of Antarctica through the development of the Circum-Antarctic Current occurred later, near the Oligocene/Miocene boundary. Keller and Barron (1983) cited these later circulation changes as the cause of hiatus PH, which they reported as occurring at Deep Sea Drilling Project (DSDP) Site 289 on the Ontong Java Plateau. No evidence of this hiatus was noted at Site 807, where planktonic foraminifers are abundant and moderately well to well-preserved in the continuous section across the boundary.

The two curves for the frequency of Neogene biserial planktonic foraminifers generally drop during the initial low sea stand and then recover during rising sea level and high sea stands (Fig. 2). This pattern is particularly well developed in the uppermost Miocene and Pliocene, where high-amplitude fluctuations in sea level occur. Late Miocene Zone N16 diverges most from the basic pattern, but the metric range between high and low sea stands is not great in that interval. The frequency of Streptochilus is diminished in the latest Pliocene and Pleistocene, where the numerous fluctuations of ice volume as seen in the oxygen isotopic record (Emiliani, 1955; Shackleton and Opdyke, 1973, 1976) may have disrupted the stable structure of the upper water column necessary for the proliferation of Streptochilus. In this regard, note that the eustatic sea-level curve reproduced in Figure 2 is based on first-, second-, and third-order onlap and offlap events, whereas fourth- and fifth-order events are probably reflected in the isotopic signatures (Vail and Haq, 1988). Higher resolution of both the eustatic sea-level curve and the biostratigraphic time scale (possibly with the addition of stable isotope data, in the absence of continuous paleomagnetic data at these low-latitude sites) is necessary to investigate the detailed relationships between peaks and valleys of the curves.

\section{Species Turnovers}

\section{Species Ranges}

The stratigraphic ranges of species in the two sections studied (Table 4 and Fig. 3) tend to overlap in the Paleogene. In the Neogene, a succession of species occurs, with each new addition replacing the older species through time. These Neogene ranges closely approximate those determined for the Eauripik Rise (Table 4) and Ninetyeast Ridge sections (Resig, 1989).

The Neogene species have been illustrated previously (Brönnimann and Resig, 1971; Resig and Kroopnick, 1983; Resig, 1989). The youngest species, $S$. globulosum, occurs in the surface sediments of the Ontong Java Plateau and has been found in plankton samples from the Indian Ocean (D. Kroon in De Klasz et al., 1988), estab- lishing it as an extant species. It has a continuous range and is the only biserial species present from just before the first left-to-right coiling change of Pulleniatina in Zone N19/N20 to the present. A single occurrence of the species at about 5.3 Ma was sampled at Site 806 but not at Site 807. This range is at odds with the middle Miocene through lower Pleistocene composite range given by Fordham (1986) for occurrences at DSDP Site 208 on the Lord Howe Rise and DSDP Site 77 in the central equatorial Pacific. Fordham considers variability in $S$. globulosum to represent $S$. latum or $S$. pristinum and also the reverse, and thus the longer range he attributes to the species is a result principally of differences between us in taxonomic interpretation. However, the single latest Miocene occurrence reported in this study suggests that the species may have evolved sometime before becoming the sole species. Jenkins and Srinivasan (1986) reported S. globulosum only within Zone N21 at DSDP Site 586 (Ontong Java Plateau) and at Site 587 (Lord Howe Rise).

Streptochilus globigerum ranges from near the top of Subzone $\mathrm{N} 17 \mathrm{~b}$ to Zone $\mathrm{N} 19 / \mathrm{N} 20$ below the first left-to-right coiling change of Pulleniatina, just before or coincident with the beginning of the continuous range of $S$. globulosum. Fordham (1986) has described $S$. infirmirugosus for specimens with weakly pustulose to weakly rugose texture and moderately globular chambers that increase moderately and regularly in size. The type level is lower Pliocene of the Lord Howe Rise, but the indicated range follows that of $S$. globigerum downward to late Miocene Zone N15. According to the distribution reported here and in previous studies of the Eauripik Rise and Ninetyeast Ridge, an interval with smooth-walled $S$. latum separates two intervals of cancellate-textured Streptochilus. Specimens of the upper interval are assigned to $S$. globigerum (type level Pliocene) and those of the lower interval to $S$. subglobigerum Resig (1989), a species that tends to be more finely cancellate and more rapidly expanding than $S$. globigerum. In this interpretation, the $S$. infirmirugosus morphotypes are considered within the range of variability of $S$. globigerum. The stratigraphically separate species $S$. subglobigerum is also variable and contains some moderately expanding specimens similar to the type of $S$. infirmirugosus. Fordham (1986) shows stratigraphic groupings of cancellate vs. smooth species at DSDP Site 208, Lord Howe Rise, that approximate the stratigraphic alternation of cancellate and smooth species presented here. This interpretation is therefore retained in this study.

Streptochilus latum ranges from the upper part of Zone N16, where it overlaps the LO of $S$. subglobigerum, to the upper part of Subzone $17 \mathrm{~b}$, just before or coincident with the appearance of $S$. globigerum. Typical specimens illustrated by Fordham (1986, plate 1, figs. 122 and 123) are from Zone N17.

Streptochilus subglobigerum first occurs in Zone N15 and can be used to recognize that zone. It ranges to upper Zone N16.

Streptochilus pristinum occurs sporadically from lower Miocene Zone N4 to late Miocene Zone N16. Its most consistent occurrences are indicated by a bar on Figure 2. Jenkins and Srinivasan (1986) reported this species in the upper Oligocene strata of DSDP Site 593 on Lord Howe Rise. Because of its relatively low abundances and sporadic distribution, the complete range is difficult to establish.

The middle Eocene (part) to Oligocene biserial planktonic species occurring in the stratigraphic section of Site 807 are illustrated in Plate 1. The specimens are presented in stratigraphic order from youngest to oldest, and examples of varying morphology both stratigraphically and in a single sample are shown.

Chiloguembelina cubensis ranges from late Eocene, lower Zone $\mathrm{P} 15$, to late Oligocene, lower Zone P22/N4, at Site 807 . A slightly shorter range from Zones $\mathrm{P} 17$ to $\mathrm{P} 21$ was reported for it on the Manihiki Plateau (Takayanagi and Oda, 1976), whereas Toumarkine and Luterbacher (1985) show its range down to middle Eocene P11 or P12. Because of poor preservation and lithification of the strata older than middle Eocene, it is likely that the lower extent of $C$. cubensis has not yet been documented at Site 807. C. cubensis exhibits variability in the rate of expansion of the test (cf. Plate 1, 
Table 1. Census data for Hole 806B.

\begin{tabular}{|c|c|c|c|c|c|c|c|c|c|c|c|c|c|}
\hline \multirow{2}{*}{$\begin{array}{l}\text { Core, section, } \\
\text { interval }(\mathrm{cm})\end{array}$} & \multirow{2}{*}{$\begin{array}{l}\text { Depth } \\
\text { (mbsf) }\end{array}$} & \multirow{2}{*}{$\begin{array}{l}\text { Age } \\
(\mathrm{Ma})\end{array}$} & & & Strept & chilus & Plan & & Bent & thic & & & \\
\hline & & & (g) & Split-1 & No. & $\%$ & No. & $\%$ & No. & $\%$ & count & Foram/g & Strepto/g \\
\hline $130-806 \mathrm{~B}-$ & & & & & & & & & & & & & \\
\hline $1 \mathrm{H}-1,0-2$ & 0 & 0 & 8.3 & 512 & 2 & 0.2 & 1273 & 99.5 & 5 & 0.4 & 1280 & 78959 & 123 \\
\hline $1 \mathrm{H}-2,44-46$ & 1.94 & 0.20 & 10.7 & 1024 & 4 & 0.6 & 647 & 96.9 & 17 & 2.5 & 668 & 63928 & 383 \\
\hline $1 \mathrm{H}-4,44-46$ & 4.94 & 0.30 & 8.9 & 1024 & 0 & 0 & 489 & 98.8 & 6 & 1.2 & 495 & 56953 & 0 \\
\hline IH-CC & 6.50 & 0.30 & & 256 & 0 & 0 & 284 & 98.3 & 5 & 1.7 & 289 & & \\
\hline $2 \mathrm{H}-2,44-46$ & 8.44 & 0.40 & 6.3 & 1024 & 0 & 0 & 1799 & 99.8 & 3 & 0.2 & 1802 & 292897 & 0 \\
\hline $2 \mathrm{H}-4,44-46$ & 11.44 & 0.50 & 8.7 & 512 & 21 & 3.7 & 540 & 95.2 & 6 & 1.1 & 567 & 33368 & 1236 \\
\hline $2 \mathrm{H}-\mathrm{CC}$ & 16.00 & 0.60 & & 256 & 1 & 0.2 & 540 & 99,1 & 4 & 0.7 & 545 & & \\
\hline $3 \mathrm{H}-2,44-46$ & 17.94 & 0.60 & 8.4 & 1024 & 5 & 0.3 & 1848 & 97.7 & 38 & 2.0 & 1891 & 230522 & 610 \\
\hline $3 \mathrm{H}-4,44-46$ & 20.94 & 0.65 & 9.1 & 1024 & 1 & 0.1 & 836 & 98.8 & 9 & 1.1 & 846 & 95198 & 113 \\
\hline $3 \mathrm{H}-\mathrm{CC}$ & 25.60 & 0.85 & & 256 & 0 & 0 & 422 & 98.4 & 7 & 1.6 & 429 & & \\
\hline $4 \mathrm{H}-2,44-46$ & 27.44 & 0.90 & 19.7 & 1024 & 0 & 0 & 1128 & 98.9 & 12 & 1.1 & 1140 & 59257 & 0 \\
\hline $4 \mathrm{H}-4,44-46$ & 30.44 & 1.00 & 13.0 & 1024 & 0 & 0 & 511 & 99.8 & 1 & 0.2 & 512 & 40330 & 0 \\
\hline $4 \mathrm{H}-\mathrm{CC}$ & 35.00 & 1.65 & & 512 & 0 & 0 & 330 & 98.8 & 4 & 1.2 & 334 & & \\
\hline $5 \mathrm{H}-2,44-46$ & 36.94 & 1.70 & 14.0 & 1024 & 5 & 0.8 & 590 & 97.2 & 17 & 2.8 & 607 & 44398 & 366 \\
\hline $5 \mathrm{H}-4,44-46$ & 39.94 & 1.80 & 14.3 & 512 & 32 & 3.5 & 858 & 93.5 & 28 & 3.1 & 918 & 32868 & 1146 \\
\hline $5 \mathrm{H}-\mathrm{CC}$ & 44.50 & 1.89 & & 512 & 10 & 3.3 & 284 & 94.4 & 7 & 2.3 & 301 & & \\
\hline $6 \mathrm{H}-2,44-46$ & 46.44 & 1.89 & 7.5 & 128 & 55 & 7.5 & 634 & 86.3 & 46 & 6.3 & 735 & 26316 & 939 \\
\hline $6 \mathrm{H}-4,44-46$ & 49.44 & 1.90 & 15.2 & 512 & 256 & 19.1 & 1106 & 79.7 & 25 & 1.8 & 1387 & 46720 & 8623 \\
\hline $6 \mathrm{H}-\mathrm{CC}$ & 54.00 & 2.05 & & 256 & 5 & 1.3 & 370 & 97.4 & 5 & 1.3 & 380 & & \\
\hline $7 \mathrm{H}-2,44-46$ & 55.94 & 2.15 & 21.4 & 1024 & 150 & 9.5 & 1406 & 89.5 & 15 & 1.0 & 1571 & 75173 & 7178 \\
\hline $7 \mathrm{H}-4,44-46$ & 58.94 & 2.25 & 17.8 & 1024 & 153 & 12.8 & 1026 & 86.1 & 12 & 1.0 & 1191 & 68516 & 8802 \\
\hline $7 \mathrm{H}-\mathrm{CC}$ & 63.50 & 2.45 & & 256 & 73 & 18.2 & 319 & 79.6 & 9 & 2.2 & 401 & & \\
\hline $8 \mathrm{H}-2,44-46$ & 65.44 & 2.50 & 12.4 & 512 & 15 & 2.4 & 723 & 96.4 & 9 & 1.2 & 750 & 30968 & 743 \\
\hline $8 \mathrm{H}-4,44-46$ & 68.44 & 2.70 & 11.0 & 512 & 80 & 6.3 & 1164 & 91.1 & 34 & 2.7 & 1278 & 59485 & 3724 \\
\hline $8 \mathrm{H}-\mathrm{CC}$ & 73.00 & 2.80 & & 256 & 14 & 3.0 & 443 & 94.3 & 13 & 2.7 & 470 & & \\
\hline $9 \mathrm{H}-2,44-46$ & 74.94 & 2.90 & 11.5 & 512 & 7 & 1.0 & 701 & 97.5 & 11 & 1.5 & 719 & 32011 & 312 \\
\hline $9 \mathrm{H}-3,44-46$ & 76.44 & 3.00 & 9.4 & 512 & 150 & 15.7 & 838 & 82.4 & 19 & 1.9 & 1017 & 55394 & 8715 \\
\hline 9H-CC & 82.50 & 3.20 & & 512 & 144 & 17.1 & 684 & 81.4 & 12 & 1.4 & 840 & & \\
\hline $10 \mathrm{H}-2,44-46$ & 84.44 & 3.30 & 12.2 & 512 & 168 & 14.6 & 969 & 84.5 & 10 & 0.9 & 1147 & 48136 & 7050 \\
\hline $10 \mathrm{H}-4,44-46$ & 87.44 & 3.40 & 13.7 & 512 & 40 & 3.7 & 1038 & 95.2 & 12 & 1.1 & 1090 & 40736 & 1495 \\
\hline $10 \mathrm{H}-\mathrm{CC}$ & 92.00 & 3.45 & & 512 & 52 & 7.1 & 670 & 91.5 & 10 & 1.4 & 732 & & \\
\hline $11 \mathrm{H}-2,44-46$ & 93.94 & 3.50 & 15.2 & 2048 & 12 & 1.0 & 1163 & 98.1 & 11 & 0.9 & 1186 & 159798 & 1617 \\
\hline $11 \mathrm{H}-4,44-46$ & 96.94 & 3.60 & 15.2 & 512 & 1 & 0.1 & 1026 & 96.8 & 33 & 3.1 & 1060 & 35705 & 34 \\
\hline $11 \mathrm{H}-\mathrm{CC}$ & 101.60 & 3.75 & & 1024 & 2 & 0.6 & 359 & 99.4 & 0 & 0 & 361 & & \\
\hline $12 \mathrm{H}-2,44-46$ & 103.44 & 3.75 & 12.3 & 2048 & 3 & 0.3 & 1087 & 98.9 & 9 & 0.8 & 1099 & 182988 & 500 \\
\hline $12 \mathrm{H}-4,44-46$ & 106.44 & 3.80 & 15.3 & 1024 & 2 & 0.3 & 637 & 98.2 & 10 & 1.5 & 649 & 43436 & 134 \\
\hline $12 \mathrm{H}-\mathrm{CC}$ & 111.00 & 3.93 & & 512 & 1 & 0.3 & 332 & 97.1 & 9 & 2.6 & 342 & & \\
\hline $13 \mathrm{H}-2,44-46$ & 112.94 & 3.95 & 15.9 & 1024 & 376 & 22.9 & 1261 & 76.7 & 7 & 0.4 & 1644 & 105878 & 24215 \\
\hline $13 \mathrm{H}-4,44-46$ & 115.94 & 4.00 & 15.8 & 1024 & 268 & 29.5 & 636 & 70.1 & 3 & 0.3 & 907 & 58783 & 17369 \\
\hline $13 \mathrm{H}-\mathrm{CC}$ & 120.50 & 4.07 & & 1024 & 193 & 32.4 & 394 & 66.2 & 8 & 1.3 & 595 & & \\
\hline $14 \mathrm{H}-2,44-46$ & 122.44 & 4.15 & 13.9 & 1024 & 305 & 22.3 & 1053 & 77.0 & 9 & 0.7 & 1367 & 100706 & 22469 \\
\hline $14 \mathrm{H}-4,44-46$ & 125.44 & 4.18 & 15.6 & 1024 & 305 & 20.4 & 1182 & 79.0 & 9 & 0.6 & 1496 & 98199 & 20021 \\
\hline $14 \mathrm{H}-\mathrm{CC}$ & 130.00 & 4.27 & & 256 & 27 & 7.9 & 306 & 89.7 & 8 & 2.3 & 341 & & \\
\hline $15 \mathrm{H}-2,44-46$ & 131.94 & 4.30 & 12.5 & 1024 & 314 & 19.7 & 1271 & 79.9 & 6 & 0.4 & 1591 & 130335 & 25723 \\
\hline $15 \mathrm{H}-4,44-46$ & 134.94 & 4.35 & 14.1 & 1024 & 18 & 2.0 & 886 & 97.7 & 3 & 0.3 & 907 & 65870 & 1307 \\
\hline $15 \mathrm{H}-\mathrm{CC}$ & 139.50 & 4.43 & & 256 & 21 & 5.0 & 396 & 94.3 & 3 & 0.7 & 420 & & \\
\hline $16 \mathrm{H}-2,44-46$ & 141.45 & 4.45 & 13.7 & 1024 & 150 & 9.2 & 1467 & 90.4 & 6 & 0.4 & 1623 & 121310 & 11212 \\
\hline $16 \mathrm{H}-4,44-46$ & 144.44 & 4.50 & 16.4 & 1024 & 90 & 14.9 & 505 & 83.7 & 8 & 1.3 & 603 & 37651 & 5620 \\
\hline $16 \mathrm{H}-\mathrm{CC}$ & 149.00 & 4.70 & & 1024 & 28 & 10.4 & 238 & 88.1 & 4 & 1.5 & 270 & & \\
\hline $17 \mathrm{H}-2,44-46$ & 150.95 & 4.80 & 14.1 & 2048 & 88 & 12.1 & 638 & 87.6 & 2 & 0.3 & 728 & 105741 & 12782 \\
\hline $17 \mathrm{H}-4,44-46$ & 153.95 & 4.90 & 16.3 & 1024 & 49 & 5.0 & 921 & 94.6 & 4 & 0.4 & 974 & 61189 & 3078 \\
\hline $17 \mathrm{H}-\mathrm{CC}$ & 158.60 & 5.00 & & 512 & 121 & 25.5 & 345 & 72.8 & 8 & 1.7 & 474 & & \\
\hline $18 \mathrm{H}-2,44-46$ & 160.44 & 5.10 & 14.8 & 2048 & 102 & 10.7 & 844 & 88.8 & 4 & 0.4 & 950 & 131459 & 14115 \\
\hline $18 \mathrm{H}-4,44-46$ & 163.44 & 5.20 & 15.2 & 1024 & 165 & 20.0 & 659 & 79.8 & 2 & 0.2 & 826 & 55646 & 11116 \\
\hline $18 \mathrm{H}-\mathrm{CC}$ & 168.00 & 5.25 & & 1024 & 206 & 32.3 & 429 & 67.3 & 2 & 0.3 & 637 & & \\
\hline $19 \mathrm{H}-2,44-46$ & 169.94 & 5.28 & 12.3 & 1024 & 98 & 13.9 & 597 & 84.9 & 8 & 1.1 & 703 & 58526 & 8159 \\
\hline $19 \mathrm{H}-2,44-46$ & 172.94 & 5.30 & 15.9 & 2048 & 10 & 1.6 & 602 & 97.9 & 3 & 0.5 & 615 & 79215 & 1288 \\
\hline $19 \mathrm{H}-\mathrm{CC}$ & 177.50 & 5.37 & & 1024 & 57 & 14.1 & 343 & 84.7 & 5 & 1.2 & 405 & & \\
\hline $20 \mathrm{H}-2,45-47$ & 179.45 & 5.40 & 14.3 & 512 & 140 & 16.2 & 706 & 81.5 & 20 & 2.3 & 866 & 31006 & 5013 \\
\hline $20 \mathrm{H}-4,45-47$ & 182.46 & 5.45 & 11.7 & 2048 & 176 & 18.7 & 759 & 80.7 & 5 & 0.5 & 940 & 164540 & 30808 \\
\hline $20 \mathrm{H}-\mathrm{CC}$ & 187.00 & 5.51 & & 1024 & 1 & 0.3 & 283 & 98.3 & 4 & 1.4 & 288 & & \\
\hline $21 \mathrm{H}-2,44-46$ & 188.94 & 5.55 & 16.6 & 2048 & 369 & 22.8 & 1248 & 77.0 & 4 & 0.3 & 1621 & 199988 & 45525 \\
\hline $21 \mathrm{H}-4,44-46$ & 191.94 & 5.58 & 16.0 & 2048 & 175 & 25.9 & 494 & 73.1 & 7 & 1.0 & 676 & 86528 & 22400 \\
\hline $2 \mathrm{IH}-\mathrm{CC}$ & 196.50 & 5.66 & & 2048 & 39 & 2.0 & 409 & 90.5 & 4 & 0.9 & 452 & & \\
\hline $22 \mathrm{H}-2,44-46$ & 198.44 & 5.70 & 12.1 & 512 & 388 & 41.2 & 545 & 57.9 & 9 & 1.0 & 942 & 39860 & 16418 \\
\hline $22 \mathrm{H}-4,44-46$ & 201.44 & 5.75 & 16.4 & 1024 & 30 & 4.5 & 631 & 94.0 & 10 & 1.5 & 671 & 41897 & 1873 \\
\hline $22 \mathrm{H}-\mathrm{CC}$ & 206.00 & 5.80 & & 512 & 57 & 14.7 & 327 & 84.1 & 5 & 1.3 & 389 & & \\
\hline $23 \mathrm{H}-3,45-47$ & 209.45 & 5.85 & 14.7 & 1024 & 194 & 19.9 & 769 & 78.9 & 12 & 1.2 & 975 & 67918 & 13514 \\
\hline $24 \mathrm{H}-2,44-46$ & 217.44 & 6.00 & 19.0 & 2048 & 214 & 20.8 & 809 & 78.6 & 6 & 0.6 & 1029 & 110915 & 23067 \\
\hline $24 \mathrm{H}-4,44-46$ & 220.44 & 6.10 & 14.9 & 1024 & 40 & 6.0 & 622 & 93.6 & 3 & 0.5 & 655 & 45702 & 2749 \\
\hline $25 \mathrm{H}-2,44-46$ & 226.94 & 6.25 & 16.8 & 256 & 22 & 2.7 & 739 & 91.7 & 45 & 5.6 & 806 & 12282 & 335 \\
\hline $25 \mathrm{H}-4,44-46$ & 229.94 & 6.35 & 17.3 & 1024 & 30 & 5.5 & 513 & 93.8 & 4 & 0.7 & 547 & 32377 & 1776 \\
\hline $26 \mathrm{H}-2,44-46$ & 236.44 & 6.50 & 18.3 & 2048 & 30 & 3.0 & 970 & 95.8 & 12 & 1.2 & 1012 & 113256 & 3357 \\
\hline $26 \mathrm{H}-4,44-46$ & 239.44 & 6.60 & 17.3 & 1024 & 143 & 14.2 & 864 & 85.5 & 3 & 0.3 & 1010 & 59783 & 8464 \\
\hline $27 \mathrm{H}-2,44-46$ & 245.94 & 6.75 & 15.5 & 1024 & 8 & 0.9 & 905 & 98.8 & 3 & 0.3 & 916 & 60515 & 529 \\
\hline $27 \mathrm{H}-4,44-46$ & 248.94 & 6.80 & 17.3 & 1024 & 91 & 9.8 & 813 & 87.9 & 3 & 0.3 & 925 & 54751 & 5386 \\
\hline
\end{tabular}


Table 1 (continued).

\begin{tabular}{|c|c|c|c|c|c|c|c|c|c|c|c|c|c|}
\hline \multirow{2}{*}{$\begin{array}{l}\text { Core, section, } \\
\text { interval }(\mathrm{cm})\end{array}$} & \multirow{2}{*}{$\begin{array}{l}\text { Depth } \\
\text { (mbsf) }\end{array}$} & & & & Strept & chilus & Plar & tonic & Ben & & & & \\
\hline & & (Ma) & (g) & Split-1 & No. & $\%$ & No. & $\%$ & No. & $\%$ & count & Foram $/ \mathrm{g}$ & Streptolg \\
\hline $28 \mathrm{H}-2,44-46$ & 255.44 & 7.00 & 14.7 & 1024 & 65 & 6.3 & 956 & 93.2 & 5 & 0.5 & 1026 & 71471 & 4528 \\
\hline $28 \mathrm{H}-4,44-46$ & 258.44 & 7.10 & 16.0 & 1024 & 73 & 6.9 & 981 & 92.6 & 5 & 0.5 & 1059 & 67776 & 4672 \\
\hline $29 \mathrm{H}-2,44-46$ & 264.94 & 7.25 & 16.9 & 1024 & 229 & 21.0 & 861 & 78.8 & 3 & 0.3 & 1093 & 66227 & 13876 \\
\hline $29 \mathrm{H}-4,44-46$ & 267.94 & 7.40 & 16.6 & 2048 & 327 & 21.3 & 1199 & 78.1 & 9 & 0.6 & 1535 & 189378 & 40343 \\
\hline $30 \mathrm{H}-2,44-46$ & 274.44 & 7.53 & 16.7 & 1024 & 68 & 8.5 & 730 & 91.0 & 4 & 0.5 & 802 & 49177 & 4170 \\
\hline $30 \mathrm{H}-4,44-46$ & 277.44 & 7.56 & 15.8 & 1024 & 344 & 24.1 & 1073 & 75.3 & 8 & 0.6 & 1425 & 92354 & 22295 \\
\hline $31 \mathrm{H}-2,44-46$ & 283.94 & 7.62 & 16.2 & 1024 & 154 & 23.1 & 511 & 76.7 & 1 & 0.2 & 666 & 42098 & 9734 \\
\hline $31 \mathrm{H}-4,44-46$ & 286.94 & 7.65 & 17.4 & 1024 & 138 & 24.7 & 539 & 96.6 & 1 & 0.2 & 558 & 32839 & 8121 \\
\hline $32 \mathrm{H}-2,44-46$ & 293.44 & 7.70 & 14.8 & 2048 & 164 & 19.0 & 696 & 80.7 & 2 & 0.2 & 862 & 77215 & 22694 \\
\hline $32 \mathrm{H}-4,44-46$ & 296.44 & 7.75 & 16.2 & 512 & 196 & 39.2 & 302 & 60.6 & 1 & 0.2 & 498 & 15739 & 6163 \\
\hline $33 \mathrm{H}-2,44-46$ & 302.94 & 7.83 & 17.1 & 2048 & 322 & 48.4 & 342 & 51.6 & 0 & 0 & 664 & 79525 & 38565 \\
\hline $33 \mathrm{H}-4,44-46$ & 305.94 & 7.85 & 14.7 & 2048 & 75 & 11.9 & 555 & 87.9 & 1 & 0.2 & 631 & 87911 & 10449 \\
\hline $34 \mathrm{H}-2,44-46$ & 312.44 & 7.93 & 12.3 & 1024 & 341 & 41.0 & 487 & 58.6 & 3 & 0.4 & 831 & 69182 & 28389 \\
\hline $34 \mathrm{H}-4,44-46$ & 315.44 & 7.95 & 14.6 & 1024 & 327 & 26.0 & 929 & 73.9 & 1 & 0.1 & 1257 & 88162 & 22935 \\
\hline $35 X-2,44-46$ & 321.94 & 8.05 & 12.6 & 1024 & 58 & 7.2 & 747 & 92.5 & 3 & 0.4 & 808 & 65666 & 4714 \\
\hline $35 X-4,44-46$ & 324.94 & 8.10 & 13.5 & 1024 & 330 & 26.1 & 930 & 73.6 & 4 & 0.3 & 1264 & 95877 & 25031 \\
\hline $36 \mathrm{X}-2,44-46$ & 331.64 & 8.55 & 9.9 & 1024 & 20 & 4.3 & 447 & 95.5 & 1 & 0.2 & 468 & 48407 & 2069 \\
\hline $36 \mathrm{X}-4,44-46$ & 334.64 & 8.70 & 16.3 & 2048 & 17 & 3.1 & 522 & 96.7 & 1 & 0.2 & 540 & 67848 & 2136 \\
\hline $37 \mathrm{X}-2,44-46$ & 341.34 & 9.20 & 14.4 & 512 & 47 & 5.1 & 875 & 94.8 & 1 & 0.1 & 923 & 32818 & 1671 \\
\hline $37 \times-4,44-46$ & 344.34 & 9.40 & 13.0 & 1024 & 28 & 4.5 & 585 & 94.8 & 4 & 0.7 & 617 & 48601 & 2206 \\
\hline $38 \mathrm{X}-2,44-46$ & 351.04 & 9.90 & 12.7 & 256 & 38 & 5.0 & 713 & 93.7 & 10 & 1.3 & 761 & 15340 & 766 \\
\hline $38 X-4,44-46$ & 354.04 & 10.20 & 19.2 & 1024 & 5 & 0.8 & 606 & 99.0 & 1 & 0.2 & 612 & 41229 & 337 \\
\hline $39 \mathrm{X}-2,44-46$ & 360.74 & 10.35 & 14.4 & 1024 & 6 & 0.8 & 767 & 98.6 & 5 & 0.6 & 778 & 55324 & 427 \\
\hline $39 \times-4,44-46$ & 363.74 & 10.40 & 10.4 & 1024 & 0 & 0 & 695 & 99.6 & 3 & 0.4 & 698 & 68726 & 0 \\
\hline $40 X-2,44-46$ & 370.44 & 10.55 & 11.8 & 512 & 0 & 0 & 610 & 99.5 & 3 & 0.5 & 613 & 26598 & 0 \\
\hline $40 \times-4,44-46$ & 373.44 & 10.65 & 14.8 & 1024 & 0 & 0 & 678 & 99.7 & 2 & 0.3 & 680 & 47049 & 0 \\
\hline $41 X-2,44-46$ & 380.14 & 10.80 & 8.6 & 1024 & 0 & 0 & 648 & 99.8 & 1 & 0.2 & 649 & 77276 & 0 \\
\hline $41 X-4,44-46$ & 363.14 & 10.85 & 10.6 & 1024 & 28 & 4.1 & 658 & 95.9 & 0 & 0 & 696 & 66270 & 2705 \\
\hline $42 X-2,44-46$ & 389.85 & 10.95 & 10.9 & 1024 & 28 & 4.2 & 627 & 95.1 & 4 & 0.6 & 659 & 61910 & 2630 \\
\hline $42 X-4,44-46$ & 392.84 & 11.00 & 10.2 & 1024 & 2 & 0.3 & 690 & 99.0 & 5 & 0.7 & 697 & 69973 & 201 \\
\hline $43 X-2,44-46$ & 399.44 & 11.20 & 11.1 & 512 & 0 & 0 & 916 & 99.6 & 4 & 0.4 & 920 & 42436 & 0 \\
\hline $43 X-4,44-46$ & 402.44 & 11.35 & 12.6 & 1024 & 0 & 0 & 1014 & 99.6 & 4 & 0.4 & 1018 & 82733 & 0 \\
\hline $44 X-2,44-46$ & 409.14 & 11.40 & 11.5 & 1024 & 0 & 0 & 782 & 100.0 & 0 & 0 & 782 & 69632 & 0 \\
\hline $44 X-4,44-46$ & 412.14 & 11.50 & 15.9 & 2048 & 0 & 0 & 749 & 99.9 & 1 & 0.1 & 750 & 96604 & 0 \\
\hline $45 \times-4,44-46$ & 421.84 & 12.10 & 17.4 & 2048 & 0 & 0 & 654 & 99.5 & 3 & 0.5 & 657 & 77330 & 0 \\
\hline $46 \mathrm{X}-2,44-46$ & 428.44 & 12.50 & 11.1 & 2048 & 0 & 0 & 504 & 100.0 & 0 & 0 & 504 & 92990 & 0 \\
\hline $46 \mathrm{X}-4,44-46$ & 431.48 & 12.70 & 13.3 & 1024 & 0 & 0 & 560 & 99.6 & 2 & 0.4 & 562 & 43270 & 0 \\
\hline $47 \times-2,44-46$ & 438.04 & 12.95 & 12.4 & 2048 & 0 & 0 & 490 & 99.6 & 2 & 0.4 & 492 & 81259 & 0 \\
\hline $47 \times-4,44-46$ & 441.04 & 13.00 & 10.0 & 1024 & 0 & 0 & 630 & 100.0 & 0 & 0 & 630 & 64512 & 0 \\
\hline $48 X-2,44-46$ & 447.74 & 13.20 & 12.3 & 1024 & 0 & 0 & 489 & 99.6 & 2 & 0.4 & 491 & 40877 & 0 \\
\hline $48 X-4,44-46$ & 450.74 & 13.20 & 12.1 & 1024 & 0 & 0 & 885 & 99.8 & 2 & 0.2 & 887 & 75065 & 0 \\
\hline $49 \times-2,44-46$ & 457.44 & 13.30 & 12.4 & 1024 & 0 & 0 & 654 & 100.0 & 0 & 0 & 654 & 54008 & 0 \\
\hline $49 \times-4,44-46$ & 460.44 & 13.35 & 16.4 & 1024 & 0 & 0 & 633 & 100.0 & 0 & 0 & 633 & 39524 & 0 \\
\hline $50 \times-2,44-46$ & 465.54 & 13.40 & 7.9 & 512 & 0 & 0 & 512 & 99.6 & 2 & 0.4 & 514 & 33312 & 0 \\
\hline $50 \times-4,44-46$ & 468.64 & 13.45 & 10.5 & 1024 & 0 & 0 & 623 & 99.8 & 1 & 0.2 & 624 & 60855 & 0 \\
\hline $51 \times-2,44-46$ & 475.24 & 13.55 & 11.3 & 2048 & 0 & 0 & 858 & 99.9 & i & 0.1 & 859 & 155684 & 0 \\
\hline $51 X-4,44-46$ & 478.24 & 13.60 & 14.9 & 2048 & 0 & 0 & 865 & 99.8 & 2 & 0.2 & 867 & 119169 & 0 \\
\hline $52 \mathrm{X}-2,44-46$ & 484.54 & 13.65 & 14.1 & 2048 & 0 & 0 & 546 & 100.0 & 0 & 0 & 546 & 79306 & 0 \\
\hline $53 X-2,44-46$ & 494.24 & 13.75 & 11.4 & 512 & 0 & 0 & 607 & 99.5 & 3 & 0.5 & 610 & 27396 & 0 \\
\hline $53 \mathrm{X}-4,44-46$ & 497.24 & 13.80 & 10.4 & 1024 & 0 & 0 & 522 & 99.4 & 3 & 0.6 & 525 & 51692 & 0 \\
\hline $54 X-2,44-46$ & 503.84 & 13.83 & 8.6 & 1024 & 2 & 0.3 & 645 & 99.7 & 0 & 0 & 647 & 77038 & 0 \\
\hline $54 \mathrm{X}-4,44-46$ & 506.84 & 13.85 & 14.2 & 1024 & 0 & 0 & 612 & 99.2 & 5 & 0.8 & 617 & 44494 & 0 \\
\hline $55 \mathrm{X}-2,44-46$ & 513.54 & 13.90 & 11.0 & 1024 & 42 & 4.5 & 890 & 95.4 & 1 & 0.1 & 933 & 86854 & 3910 \\
\hline $55 \mathrm{X}-4,44-46$ & 516.54 & 14.10 & 11.1 & 1024 & 14 & 2.5 & 552 & 97.5 & 0 & 0 & 566 & 52215 & 1292 \\
\hline $56 \mathrm{X}-2,44-46$ & 523.26 & 14.50 & 12.8 & 1024 & 0 & 0 & 518 & 99.6 & 2 & 0.4 & 520 & 41600 & 0 \\
\hline $56 \times-4,44-46$ & 526.24 & 15.10 & 13.9 & 256 & 0 & 0 & 660 & 99.2 & 5 & 0.8 & 665 & 12247 & 0 \\
\hline $57 X-2,44-46$ & 532.84 & 15.50 & 12.0 & 1024 & 0 & 0 & 935 & 100.0 & 0 & 0 & 935 & 79787 & 0 \\
\hline $58 \mathrm{X}-2,44-46$ & 542.44 & 16.00 & 10.1 & 512 & 0 & 0 & 845 & 99.9 & 1 & 0.1 & 846 & 42886 & 0 \\
\hline $59 \mathrm{X}-2,44-46$ & 552.14 & 16.30 & 9.2 & 512 & 0 & 0 & 995 & 99.9 & 1 & 0.1 & 996 & 55430 & 0 \\
\hline $60 \times-2,44-46$ & 561.83 & 16.60 & 15.4 & 2048 & 0 & 0 & 935 & 99.8 & 2 & 0.2 & 937 & 124609 & 0 \\
\hline $61 X-2,44-46$ & 571.64 & 16.80 & 12.0 & 1024 & 0 & 0 & 973 & 100.0 & 0 & 0 & 973 & 83029 & 0 \\
\hline $62 X-2,44-46$ & 581.24 & 17.00 & 14.1 & 1024 & 0 & 0 & 941 & 99.4 & 3 & 0.3 & 947 & 68775 & 0 \\
\hline $63 X-2,44-46$ & 590.94 & 17.30 & 12.4 & 512 & 0 & 0 & 1080 & 100.0 & 0 & 0 & 1080 & 44594 & 0 \\
\hline $64 \mathrm{X}-2,44-46$ & 600.54 & 17.60 & 10.9 & 2048 & 0 & 0 & 971 & 99.9 & 1 & 0.1 & 972 & 182629 & 0 \\
\hline $65 X-2,44-46$ & 610.00 & 19.10 & 12.0 & 2048 & 0 & 0 & 550 & 100.0 & 0 & 0 & 550 & 93867 & 0 \\
\hline $66 \mathrm{X}-2,44-46$ & 619.84 & 20.50 & 12.1 & 2048 & 0 & 0 & 947 & 100.0 & 0 & 0 & 947 & 160286 & 0 \\
\hline $67 \times-2,44-46$ & 629.44 & 21.00 & 11.1 & 2048 & 0 & 0 & 800 & 99.8 & 2 & 0.3 & 802 & 147973 & 0 \\
\hline $69 \times-2,44-46$ & 648.44 & 21.30 & 13.3 & 1024 & 0 & 0 & 493 & 99.8 & 1 & 0.2 & 494 & 38034 & 0 \\
\hline $70 \times-2,44-46$ & 658.14 & 21.70 & 9.0 & 1024 & 0 & 0 & 681 & 99.9 & 1 & 0.2 & 682 & 77596 & 0 \\
\hline $71 X-2,44-46$ & 667.74 & 22.00 & 11.4 & 256 & 0 & 0 & 540 & 100.0 & 0 & 0 & 540 & 12126 & 0 \\
\hline $72 X-2,44-46$ & 677.42 & 22.50 & 11.4 & 256 & 0 & 0 & 1416 & 100.0 & 0 & 0 & 1416 & 31798 & 0 \\
\hline $73 \times-2,44-46$ & 687.14 & 23.00 & 18.4 & 1024 & 0 & 0 & 497 & 100.0 & 0 & 0 & 497 & 27659 & 0 \\
\hline $74 X-2,44-46$ & 696.74 & 23.50 & 17.1 & 2048 & 0 & 0 & 638 & 99.4 & 1 & 0.2 & 639 & 76531 & 0 \\
\hline $75 \times-2,44-46$ & 706.45 & 23.80 & 13.0 & 1024 & 0 & 0 & 858 & 99.5 & 4 & 0.5 & 862 & 67899 & 0 \\
\hline $75 X-4,44-46$ & 709.44 & 23.90 & 15.4 & 2048 & 0 & 0 & 644 & 100.0 & 0 & 0 & 644 & 85644 & 0 \\
\hline $76 \times-2,44-46$ & 716.00 & 24.00 & 10.9 & 1024 & 6 & 1.2 & 490 & 98.8 & 0 & 0 & 496 & 46597 & 564 \\
\hline 76X-CC & 718.83 & 24.20 & 13.3 & 1024 & 0 & 0 & 585 & 99.8 & 1 & 0.2 & 586 & 45118 & 0 \\
\hline $78 \times-1,44-46$ & 733.84 & 24.70 & 14.7 & 2048 & 0 & 0 & 1040 & 99.9 & 1 & 0.1 & 1041 & 145032 & 0 \\
\hline
\end{tabular}


Table 2. Census data for Hole 807A.

\begin{tabular}{|c|c|c|c|c|c|c|c|c|c|c|c|c|c|}
\hline \multirow{2}{*}{$\begin{array}{l}\text { Core, section, } \\
\text { interval }(\mathrm{cm})\end{array}$} & \multirow{2}{*}{$\begin{array}{l}\text { Depth } \\
\text { (mbsf) }\end{array}$} & \multirow{2}{*}{$\begin{array}{l}\text { Age } \\
\text { (Ma) }\end{array}$} & & & Strept & hilus & Plar & & Ben & & & & \\
\hline & & & $\begin{array}{l}\text { Weight } \\
\text { (g) }\end{array}$ & Split-1 & No. & $\%$ & No. & $\%$ & No. & $\%$ & $\begin{array}{l}\text { Iotal } \\
\text { count }\end{array}$ & Foram/g & Strepto/g \\
\hline $0-807 \mathrm{~A}-$ & & & & & & & & & & & & & \\
\hline IH-1, $4-6$ & 0 & 0.10 & 8.20 & 256 & 1 & 0.1 & 1015 & 98.4 & 16 & 1.6 & 1032 & 32219 & 31 \\
\hline IH $-2,44-46$ & 1.9 & 0.20 & 8.80 & 512 & $i$ & 0.2 & 661 & 99 & 6 & 0.9 & 668 & 38865 & 58 \\
\hline IH- $4,44-46$ & 4.9 & 0.40 & 11.70 & 256 & 0 & 0 & 734 & 98.1 & 14 & 1.9 & 748 & 16366 & 0 \\
\hline $2 \mathrm{H}-2,44-46$ & 8.9 & 0.50 & 9.20 & 128 & 20 & 2.5 & 750 & 95.4 & 17 & 2.1 & 795 & 11061 & 278 \\
\hline $2 \mathrm{H}-4,44-46$ & 12.3 & 0.70 & 9.90 & 256 & 0 & 0 & 1303 & 99.4 & 8 & 0.6 & 1311 & 33901 & 0 \\
\hline $3 \mathrm{H}-2,44-46$ & 18.8 & 1.25 & 12.30 & 256 & 0 & 0 & 800 & 99 & 8 & 1.0 & 808 & 16817 & 0 \\
\hline $3 \mathrm{H}-4,44-46$ & 21.8 & 1.50 & 13.00 & 512 & 4 & 0.5 & 761 & 98.2 & 10 & 1.3 & 775 & 30523 & 158 \\
\hline $4 \mathrm{H}-2,44-46$ & 28.3 & 2.00 & 13.10 & 512 & 4 & 0.4 & 1108 & 98.5 & 13 & 1.2 & 1125 & 43969 & 156 \\
\hline $4 \mathrm{H}-4,44-46$ & 31.3 & 2.10 & 11.70 & 512 & 6 & 0.9 & 666 & 96.8 & 16 & 2.3 & 688 & 30107 & 263 \\
\hline $5 \mathrm{H}-2,44-46$ & 37.8 & 2.50 & 6.20 & 512 & 423 & 28.1 & 1072 & 71.2 & 10 & 0.7 & 1505 & 12484 & 34932 \\
\hline $5 \mathrm{H}-4,44-46$ & 40.8 & 2.70 & 12.90 & 1024 & 158 & 20.9 & 590 & 78.2 & 7 & 0.9 & 755 & 59932 & 12542 \\
\hline $6 \mathrm{H}-2,44-46$ & 47.3 & 2.75 & 11.60 & 1024 & 185 & 19.1 & 777 & 80.4 & 5 & 0.5 & 967 & 85363 & 16331 \\
\hline $6 \mathrm{H}-4,44-46$ & 50.3 & 2.85 & 12.10 & 1024 & 181 & 19.6 & 739 & 80.1 & 3 & 0.3 & 923 & 78112 & 15318 \\
\hline $7 \mathrm{H}-2,44-46$ & 56.8 & 2.90 & 11.20 & 1024 & 27 & 3.0 & 857 & 96 & 9 & 1.0 & 893 & 81646 & 2469 \\
\hline $7 \mathrm{H}-4,44-46$ & 59.8 & 2.95 & 11.40 & 1024 & 2 & 0.4 & 537 & 99.3 & 2 & 0.4 & 541 & 48595 & 180 \\
\hline $8 \mathrm{H}-2,44-46$ & 66.3 & 3.30 & 11.50 & 1024 & 81 & 10.3 & 700 & 89.1 & 5 & 0.6 & 786 & 69988 & 7213 \\
\hline $8 \mathrm{H}-4,44-46$ & 69.3 & 3.45 & 11.60 & 1024 & 32 & 5.9 & 499 & 92.6 & 8 & 1.5 & 539 & 47581 & 2825 \\
\hline $9 \mathrm{H}-2,44-46$ & 75.4 & 3.48 & 9.00 & 512 & 3 & 0.4 & 746 & 98.6 & 8 & 1.1 & 757 & 43065 & 171 \\
\hline $9 \mathrm{H}-4,44-46$ & 78.4 & 3.60 & 13.10 & 512 & 2 & 0.1 & 1420 & 99.2 & 9 & 0.6 & 1431 & 55929 & 78 \\
\hline $11 \mathrm{H}-2,44-46$ & 94.8 & 4.15 & 13.30 & 1024 & 51 & 9.1 & 511 & 90.8 & 1 & 0.2 & 563 & 43347 & 3927 \\
\hline $11 \mathrm{H}-4,44-48$ & 97.8 & 4.24 & 13.00 & 512 & 75 & 7.7 & 890 & 91.9 & 4 & 0.4 & 969 & 38164 & 2954 \\
\hline $12 \mathrm{H}-4,44-46$ & 107.3 & 4.53 & 11.30 & 1024 & 62 & 9.3 & 606 & 90.6 & 1 & 0.2 & 669 & 60624 & 5618 \\
\hline $13 \mathrm{H}-2,44-46$ & 113.8 & 4.85 & 11.30 & 512 & 215 & 14.4 & 1268 & 85.2 & 6 & 0.4 & 1489 & 67466 & 9742 \\
\hline $13 \mathrm{H}-4,44-46$ & 116.8 & 4.90 & 12.20 & 1024 & 113 & 9.1 & 1127 & 90.5 & 6 & 0.5 & 1246 & 104582 & 9485 \\
\hline $14 \mathrm{H}-2,44-46$ & 123.3 & 4.95 & 12.90 & 512 & 18 & 2.6 & 665 & 95.5 & 13 & 1.9 & 696 & 27624 & 714 \\
\hline $14 \mathrm{H}-4,44-46$ & 126.3 & 5.05 & 8.00 & 512 & 95 & 11.4 & 736 & 88.1 & 4 & 0.5 & 835 & 53440 & 6080 \\
\hline $15 \mathrm{H}-2,44-46$ & 132.8 & 5.10 & 11.50 & 256 & 125 & 9.1 & 1239 & 90.1 & 11 & 0.8 & 1375 & 30609 & 2783 \\
\hline $15 \mathrm{H}-4,44-46$ & 135.8 & 5.20 & 11.70 & 1024 & 250 & 18.5 & 1099 & 81.3 & 3 & 0.2 & 1352 & 118329 & 21800 \\
\hline $16 \mathrm{H}-2,44-46$ & 142.3 & 5.30 & 13.10 & 256 & 21 & 4.1 & 478 & 94.3 & 8 & 1.6 & 507 & 9908 & 410 \\
\hline $16 \mathrm{H}-4,44-46$ & 145.3 & 5.40 & 12.60 & 256 & 70 & 8.8 & 717 & 90 & 10 & 1.3 & 797 & 16193 & 1422 \\
\hline $17 \mathrm{H}-2,45-47$ & 151.8 & 5.45 & 12.20 & 1024 & 480 & 34.9 & 893 & 65 & 1 & 0.1 & 1374 & 115326 & 40289 \\
\hline $17 \mathrm{H}-4,44-48$ & 154.8 & 5.50 & 12.40 & 512 & 152 & 13.7 & 950 & 85.7 & 7 & 0.6 & 1109 & 45791 & 6276 \\
\hline $18 \mathrm{H}-2,44-46$ & 161.3 & 5.80 & 11.90 & 512 & 42 & 7.5 & 516 & 91.8 & 4 & 0.7 & 562 & 24180 & 1807 \\
\hline $18 \mathrm{H}-4,44-46$ & 164.3 & 6.00 & 13.60 & 512 & 218 & 21.5 & 793 & 78.1 & 5 & 0.5 & 1016 & 38249 & 8207 \\
\hline $19 \mathrm{H}-2,44-46$ & 170.8 & 6.30 & 12.10 & 1024 & 263 & 34.7 & 488 & 64.4 & 7 & 0.9 & 758 & 64148 & 22257 \\
\hline $19 \mathrm{H}-4,44-48$ & 173.8 & 6.45 & 12.20 & 512 & 172 & 16.6 & 859 & 82.8 & 6 & 0.6 & 1037 & 43520 & 7218 \\
\hline $20 \mathrm{H}-2,44-46$ & 180.3 & 6.80 & 11.40 & 512 & 347 & 22 & 1226 & 77.6 & 6 & 0.4 & 1579 & 70916 & 15585 \\
\hline $20 \mathrm{H}-4,43-45$ & 183.3 & 6.90 & 12.00 & 512 & 120 & 9.5 & 1136 & 90.0 & 6 & 0.5 & 1262 & 53845 & 5120 \\
\hline $21 \mathrm{H}-2,44-46$ & 189.8 & 7.00 & 12.10 & 1024 & 122 & 14 & 746 & 85.6 & 4 & 0.5 & 872 & 73796 & 10325 \\
\hline $22 \mathrm{H}-4,44-46$ & 202.3 & 7.25 & 14.10 & 512 & 14 & 1.6 & 846 & 97.6 & 7 & 0.8 & 867 & 31483 & 508 \\
\hline $23 \mathrm{H}-2,44-46$ & 208.8 & 7.30 & 12.40 & 512 & 8 & 0.8 & 1046 & 99.0 & 3 & 0.3 & 1057 & 43644 & 330 \\
\hline $23 \mathrm{H}-4,44-48$ & 211.8 & 7.30 & 13.50 & 512 & 7 & 0.9 & 745 & 98.5 & 4 & 0.5 & 756 & 28672 & 265 \\
\hline $24 \mathrm{H}-2,44-46$ & 218.3 & 7.35 & 12.50 & 512 & 312 & 29.9 & 727 & 69.7 & 4 & 0.4 & 1043 & 42721 & 12780 \\
\hline $24 \mathrm{H}-4,44-46$ & 221.3 & 7.35 & 14.30 & 512 & 350 & 31 & 776 & 68.6 & 5 & 0.4 & 1131 & 40495 & 12531 \\
\hline $25 \mathrm{H}-2,44-46$ & 227.8 & 7.40 & 12.80 & 512 & 264 & 30.1 & 609 & 69.5 & 3 & 0.3 & 876 & 35040 & 10580 \\
\hline $25 \mathrm{H}-4,44-46$ & 230.8 & 7.45 & 11.20 & 256 & 268 & 18.5 & 1172 & 81.1 & 6 & 0.4 & 1446 & 33051 & 6126 \\
\hline $26 \mathrm{H}-2,44-46$ & 237.3 & 7.50 & 7.50 & 128 & 105 & 16.2 & 536 & 82.8 & 6 & 0.9 & 647 & 11042 & 1792 \\
\hline $26 \mathrm{H}-4,44-48$ & 240.3 & 7.50 & 6.40 & 256 & 322 & 32.9 & 657 & 67.0 & 1 & 0.1 & 980 & 29867 & 9813 \\
\hline $27 \mathrm{H}-2,44-46$ & 246.8 & 7.70 & 11.30 & 512 & 184 & 26 & 520 & 73.6 & 3 & 0.4 & 707 & 32034 & 8337 \\
\hline $27 \mathrm{H}-4,44-46$ & 249.8 & 7.75 & 8.60 & 256 & 374 & 27.3 & 993 & 72.5 & 2 & 0.2 & 1369 & 40752 & 11133 \\
\hline $28 \times-2,44-46$ & 256.3 & 7.80 & 11.90 & 256 & 193 & 27.1 & 515 & 72.2 & 5 & 0.7 & 713 & 15338 & 4152 \\
\hline $28 X-4,44-46$ & 259.3 & 7.90 & 12.30 & 512 & 164 & 23.9 & 520 & 75.8 & 2 & 0.3 & 686 & 28555 & 6827 \\
\hline $29 X-2,44-46$ & 266.0 & 8.50 & 13.40 & 512 & 96 & 16.8 & 475 & 83.0 & $i$ & 0.2 & 572 & 21856 & 3668 \\
\hline $29 \mathrm{X}-4,44-46$ & 269.0 & 9.00 & 13.50 & 256 & 440 & 24.6 & 1342 & 74.9 & 10 & 0.6 & 1792 & 33982 & 8344 \\
\hline $30 \times-2,44-46$ & 275.7 & 10.00 & 11.80 & 256 & 124 & 14.8 & 703 & 83.7 & 13 & 1.6 & 840 & 18224 & 2690 \\
\hline $30 \times-4,44-46$ & 278.7 & 10.20 & 10.70 & 126 & 54 & 6.3 & 796 & 92.9 & 7 & 0.8 & 857 & 10252 & 646 \\
\hline $31 \mathrm{X}-2,44-46$ & 285.4 & 10.30 & 12.60 & 256 & 221 & 18.2 & 990 & 81.5 & 4 & 0.3 & 1215 & 24686 & 4490 \\
\hline $31 X-4,44-46$ & 288.4 & 10.35 & 14.10 & 256 & 5 & 0.7 & 704 & 98.5 & 8 & 0.8 & 715 & 12982 & 91 \\
\hline $32 X-2,44-46$ & 294.6 & 10.38 & 10.40 & 256 & 0 & 0 & 800 & 99.8 & 2 & 0.3 & 802 & 19742 & 0 \\
\hline $32 X-4,44-46$ & 297.6 & 10.40 & 9.10 & 256 & 0 & 0 & 607 & 99.2 & 5 & 0.8 & 612 & 17217 & 0 \\
\hline $33 \mathrm{X}-2,44-46$ & 304.2 & 11.05 & 11.20 & 256 & 0 & 0 & 965 & 99.4 & 6 & 0.6 & 971 & 22194 & 0 \\
\hline $33 \mathrm{X}-4,44-46$ & 307.2 & 11.10 & 9.20 & 256 & 0 & 0 & 693 & 99.7 & 2 & 0.3 & 695 & 19339 & 0 \\
\hline $34 X-2,44-46$ & 313.9 & 11.25 & 13.80 & 512 & 36 & 5 & 677 & 94.4 & 4 & 0.6 & 717 & 26602 & 1336 \\
\hline $34 \mathrm{X}-4,44-46$ & 316.9 & 11.35 & 11.40 & 256 & 53 & 6.2 & 796 & 93.5 & 2 & 0.2 & 851 & 19110 & 1190 \\
\hline $35 X-2,44-46$ & 323.1 & 11.40 & 8.60 & 256 & 0 & 0 & 728 & 99.7 & 2 & 0.3 & 730 & 21730 & 0 \\
\hline $35 \mathrm{X}-4,44-46$ & 326.1 & 11.50 & 9.90 & 256 & 1 & 0.1 & 809 & 99.6 & 2 & 0.3 & 812 & 20997 & 26 \\
\hline $36 \times-2,44-46$ & 332.8 & 11.75 & 9.30 & 256 & 0 & 0 & 1095 & 99.8 & 2 & 0.2 & 1097 & 30197 & 0 \\
\hline $36 \times-4,44-46$ & 335.8 & 11.80 & 7.70 & 512 & 0 & 0 & 631 & 99.8 & $i$ & 0.2 & 632 & 42024 & 0 \\
\hline $37 X-2,44-46$ & 342.5 & 12.20 & 8.20 & 512 & 0 & 0 & 643 & 99.8 & 1 & 0.2 & 644 & 40211 & 0 \\
\hline $37 X-4,44-46$ & 345.5 & 12.40 & 8.30 & 512 & 1 & 0.2 & 615 & 99.5 & 2 & 0.3 & 618 & 38122 & 62 \\
\hline $38 \times-2,45-47$ & 352.1 & 12.70 & 10.60 & 512 & 0 & 0 & 822 & 99.8 & 2 & 0.2 & 824 & 39801 & 0 \\
\hline $38 X-4,44-46$ & 355.1 & 12.90 & 12.40 & 256 & 0 & 0 & 693 & 99.7 & 2 & 0.3 & 695 & 14348 & 0 \\
\hline $39 X-2,46-48$ & 361.8 & 13.10 & 8.20 & 256 & 0 & 0 & 990 & 99.6 & 4 & 0.4 & 994 & 31032 & 0 \\
\hline $39 X-4,44-46$ & 364.8 & 13.20 & 7.20 & 256 & 0 & 0 & 809 & 99.8 & 2 & 0.3 & 811 & 28836 & 0 \\
\hline $40 \times-2,44-46$ & 371.6 & 13.40 & 10.30 & 512 & 37 & 6 & 577 & 93.8 & 1 & 0.2 & 615 & 30571 & 1839 \\
\hline
\end{tabular}


Table 2 (continued).

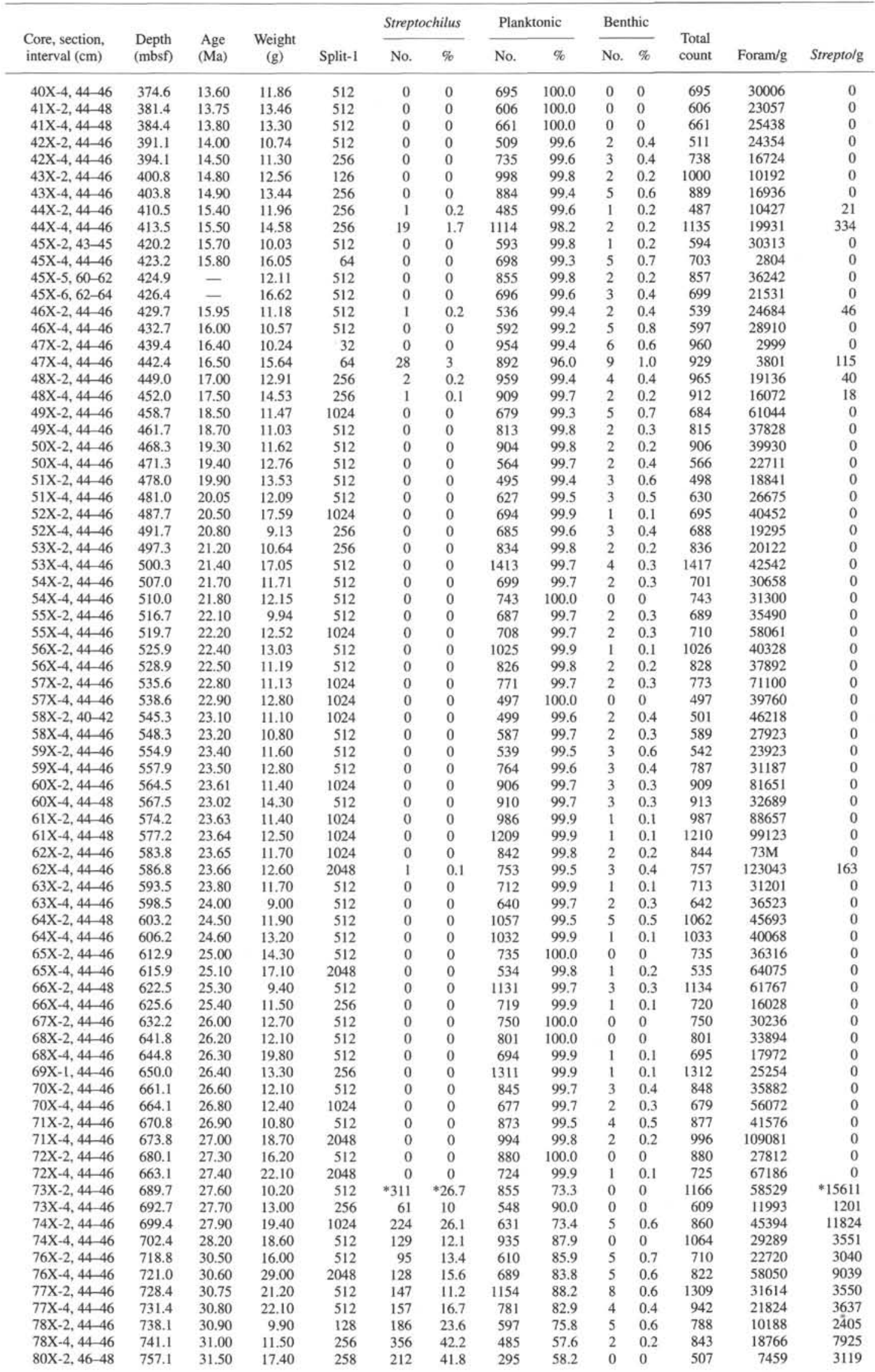


Table 2 (continued).

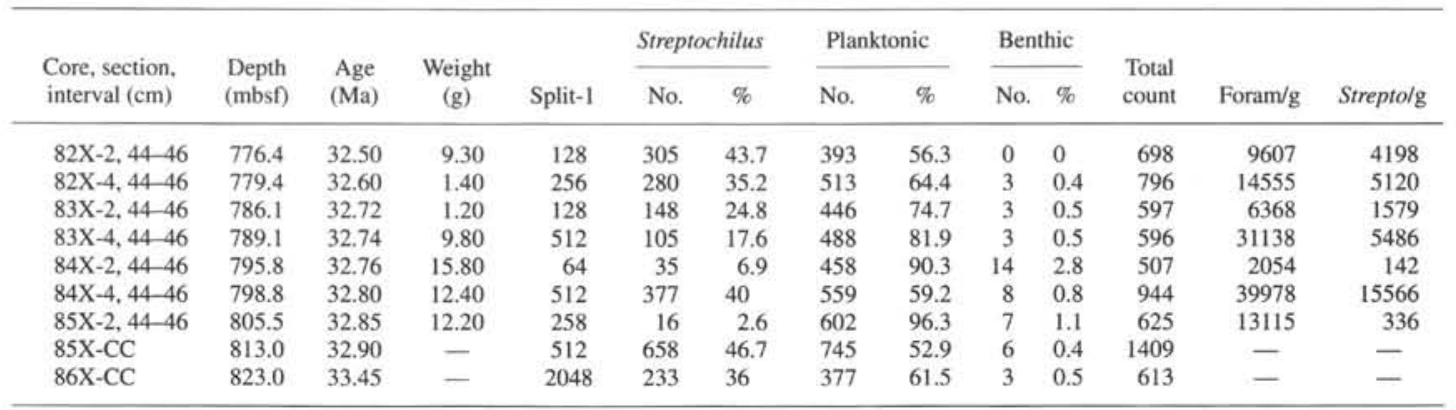

*Chiloguembelina and Streptochilus from Samples 130-807A-73X-2 to -86X-CC.

Table 3. Census data for Hole 807C.

\begin{tabular}{|c|c|c|c|c|c|c|c|c|c|c|c|c|c|}
\hline \multirow{2}{*}{$\begin{array}{l}\text { Core, section, } \\
\text { interval (cm) }\end{array}$} & \multirow{2}{*}{$\begin{array}{l}\text { Depth } \\
\text { (mbsf) }\end{array}$} & \multirow{2}{*}{$\begin{array}{l}\text { Age } \\
\text { (Ma) }\end{array}$} & \multirow{2}{*}{$\begin{array}{l}\text { Weight } \\
(\mathrm{g})\end{array}$} & \multirow[b]{2}{*}{ Split-1 } & \multicolumn{2}{|c|}{ Streptochilus* } & \multicolumn{2}{|c|}{ Planktonic } & \multicolumn{2}{|c|}{ Benthic } & \multirow{2}{*}{$\begin{array}{l}\text { Total } \\
\text { count }\end{array}$} & \multirow[b]{2}{*}{ Foram/g } & \multirow[b]{2}{*}{ Strepto*/g } \\
\hline & & & & & No. & $\%$ & No. & $\%$ & No. & $\%$ & & & \\
\hline \multicolumn{14}{|l|}{$130-807 \mathrm{C}$ - } \\
\hline IR-CC, $11-13$ & 789.7 & 33.45 & 11.6 & 512 & 226 & 33.5 & 447 & 66.3 & 1 & 0.2 & 674 & 29749 & 9975 \\
\hline $2 R-2,44-46$ & 791.6 & 33.50 & 11.5 & 64 & 40 & 6.8 & 549 & 93.1 & 1 & 0.2 & 590 & 3283 & 223 \\
\hline 3R-CC & 809.0 & 33.59 & & 1024 & 633 & 37.2 & 1064 & 62.6 & 3 & 0.2 & 1700 & & \\
\hline $4 \mathrm{R}-2,44-46$ & 810.9 & 33.60 & 21.7 & 1024 & 293 & 58.7 & 204 & 40.9 & 2 & 0.4 & 499 & 23547 & 13826 \\
\hline $4 \mathrm{R}-\mathrm{CC}$ & 818.6 & 33.64 & & 256 & 348 & 37.7 & 568 & 61.6 & 6 & 0.7 & 922 & & \\
\hline $5 \mathrm{R}-\mathrm{CC}$ & 828.3 & 33.67 & & 512 & 123 & 23.8 & 391 & 75.8 & 3 & 0.6 & 517 & & \\
\hline $6 \mathrm{R}-2,44-46$ & 830.2 & 33.68 & 22.2 & 1024 & 543 & 67.0 & 266 & 32.8 & 2 & 0.3 & 811 & 37408 & 25046 \\
\hline $7 \mathrm{R}-\mathrm{CC}$ & 847.7 & 33.75 & & 2048 & 939 & 64.4 & 519 & 35.6 & 1 & 0.7 & 1459 & & \\
\hline 8R-CC & 857.4 & 33.79 & & 512 & 358 & 55.8 & 283 & 44.1 & 1 & 0.2 & 642 & & \\
\hline $12 R-1,42-44$ & 877.0 & 33.90 & 17.7 & 2048 & 492 & 51.2 & 466 & 48.5 & 3 & 0.3 & 981 & 111194 & 56927 \\
\hline 13R-CC & 888.9 & 35.70 & & 512 & 764 & 53.1 & 673 & 48.8 & 1 & 0.7 & 1438 & & \\
\hline $14 \mathrm{R}-\mathrm{CC}$ & 893.9 & 36.16 & & 2048 & 294 & 51.1 & 280 & 48.7 & 1 & 0.2 & 575 & & \\
\hline $15 \mathrm{R}-1,42-44$ & 894.3 & 36.20 & 9.3 & 256 & 209 & 33.2 & 540 & 66.7 & 1 & 0.1 & 810 & 22297 & 7405 \\
\hline $16 \mathrm{R}-\mathrm{CC}$ & 903.9 & 36.62 & & 512 & 4 & 2.6 & 147 & 94.2 & 5 & 3.2 & 156 & & \\
\hline $17 \mathrm{R}-\mathrm{CC}$ & 908.9 & 36.74 & & 256 & 15 & 3.0 & 475 & 96.2 & 4 & 0.8 & 494 & & \\
\hline 18R-CC, $0-2$ & 913.9 & 37.25 & 9.7 & 256 & 70 & 27.2 & 186 & 72.4 & 1 & 0.4 & 257 & 6783 & 1847 \\
\hline 19R-CC & 918.9 & 37.70 & & 512 & 108 & 19.0 & 462 & 81.1 & 0 & 0 & 570 & & \\
\hline 20R-CC & 923.9 & 38.25 & & 512 & 183 & 20.3 & 716 & 79.3 & 4 & 0.4 & 903 & & \\
\hline 21R-CC & 933.7 & 38.70 & & 256 & 72 & 18.1 & 321 & 80.7 & 5 & 1.3 & $3 \mathrm{M}$ & & \\
\hline 22R-CC & 938.7 & 39.25 & & 64 & 6 & 1.6 & 324 & 90.5 & 28 & 7.8 & 358 & & \\
\hline 23R-CC & 943.7 & 39.70 & & 64 & 82 & 18.6 & 350 & 79.5 & 8 & 1.8 & 440 & & \\
\hline 24R-CC & 948.4 & 40.25 & & 16 & 16 & 4.8 & 248 & 75.6 & 64 & 19.5 & 328 & & \\
\hline 25R-CC & 958.1 & 40.70 & & 64 & 104 & 24.8 & 312 & 74.5 & 3 & 0.7 & 419 & & \\
\hline
\end{tabular}

*Streptochilus and Chiloguembelina.

Table 4. First and last occurrences of biserial planktonic species at ODP Sites 806 and 807 and DSDP Site 62.

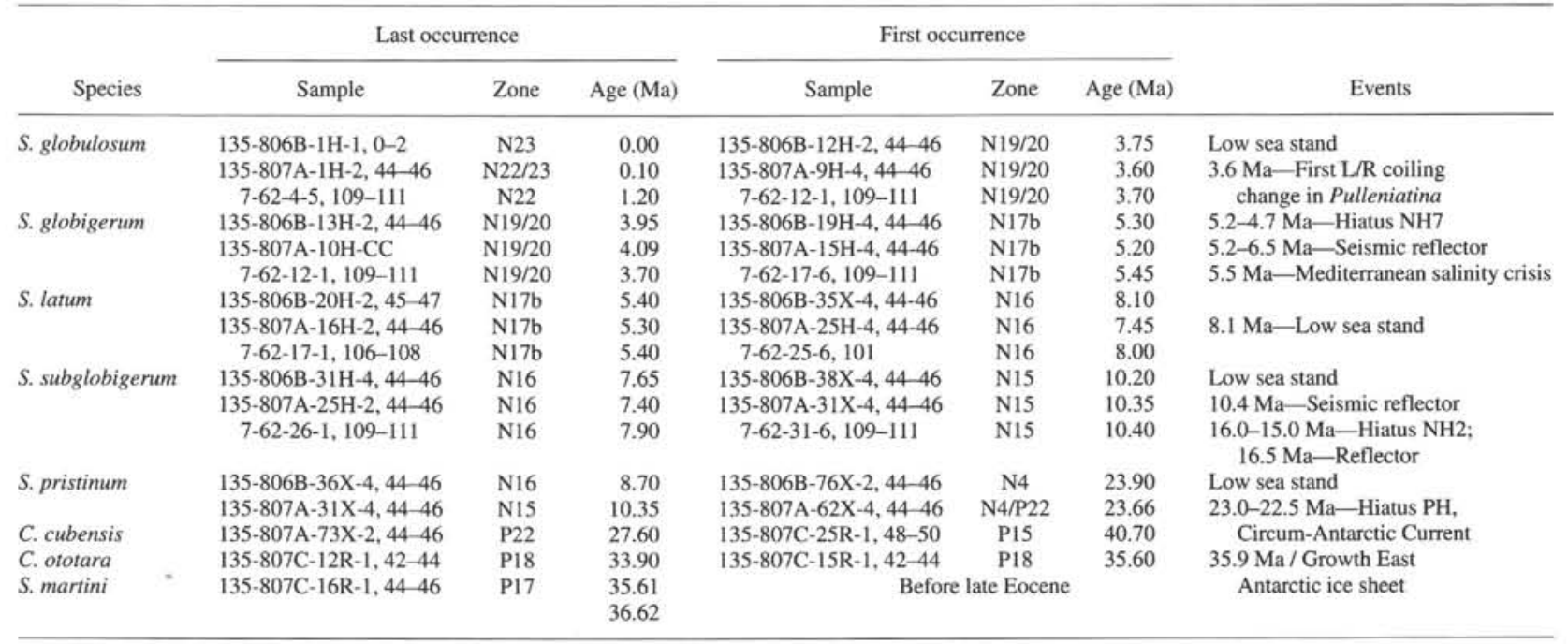

Note: DSDP Site 62 data from Resig (1989). 


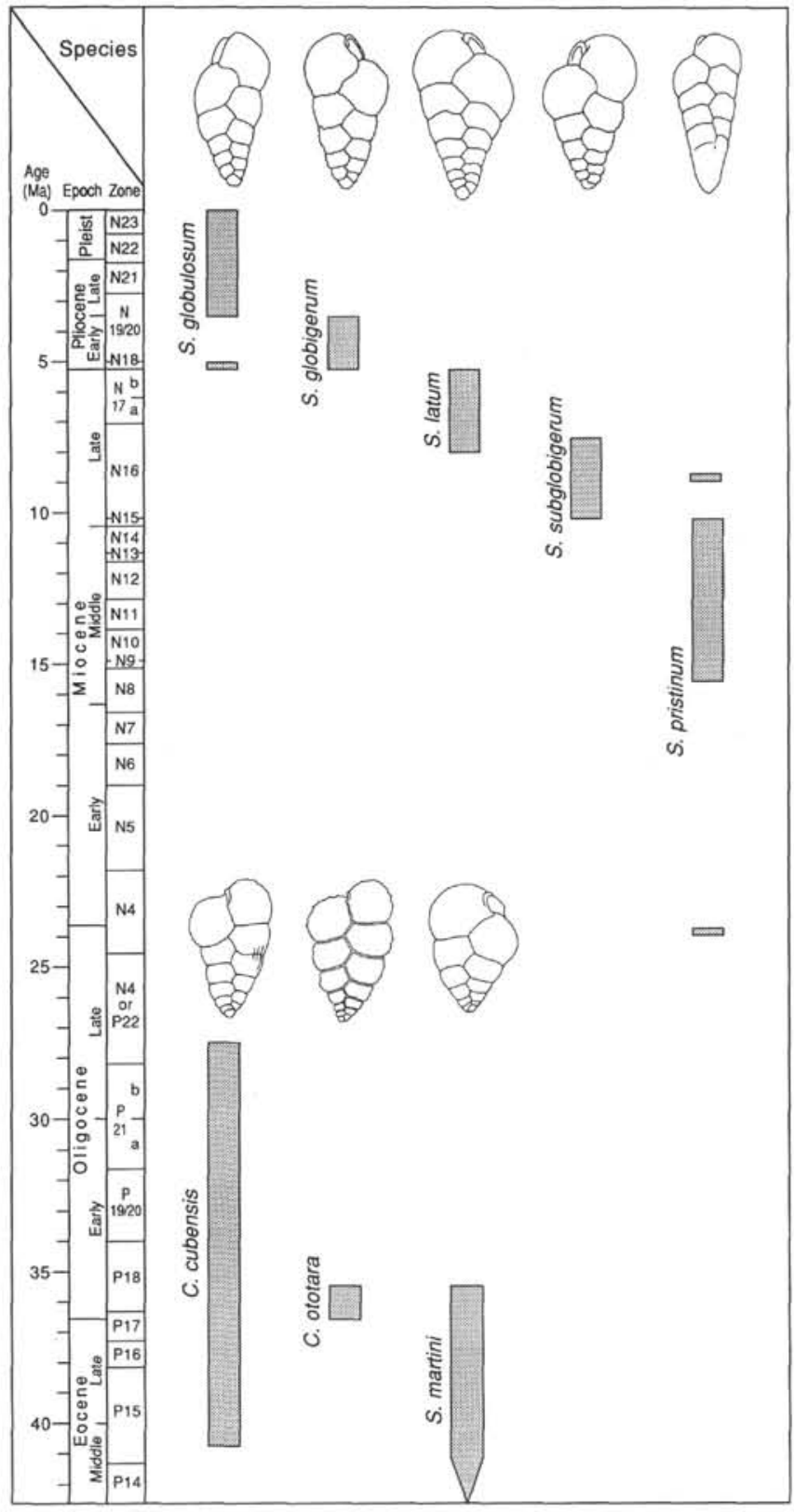

Figure 3. Stratigraphic ranges of Paleogene and Neogene species of biserial planktonic foraminifers at Sites 806 and 807.

Figs. 1 and 3) and in the proportion of costate to pustulose chambers (cf. Plate 1, Figs. 1, 4, and 7). On the oldest specimens, which exhibit poor preservation, the costae are reduced to short bars visible near the sutures (Plate 1, Fig. 17). Rare specimens exhibit multiple chambers in the final series (Plate 1, Fig. 6). The specimens have low arched apertures with a rim and are symmetrical to slightly asymmetrical in the later chambers. In chambers before the last one or two, the rim bends inward on one side to touch the rim of the preceding foramen (Plate 1, Fig. 8), in the manner described by Poore and Gosnell (1985).

Chiloguembelina ototara (Plate 1, Fig. 9) occurs in two samples just above the Eocene/Oligocene boundary. The chambers of this species are pustulose and the sutures are incised. Hornibrook (1990) indicates its range in New Zealand as middle Eocene (Bartonian) to lower Oligocene (lower Whaingaroan). Therefore, the occurrence at Site 807 represents a minor part of its total range.
Streptochilus martini (Plate 1, Fig. 11) last occurs at the Eocene/Oligocene boundary at Site 807 and extends downward at least into the middle Eocene, where preservation of foraminiferal tests deteriorates. Beckmann (1957) gives its range as lower Eocene to the Eocene/Oligocene boundary. Some of the specimens are comparatively large and have roughened lower surfaces (Plate 1, Figs. 15 and 16), which may result from corrosion or, alternatively, represent another species. The specimens have an internal plate connecting foramina (Plate 1, Fig. 12), as described by Poore and Gosnell (1985).

\section{Evolution and Extinction Events}

Two Paleogene last occurrence events, those of Streptochilus martini (between 35.6 and $36.6 \mathrm{Ma}$ ) and Chiloguembelina cubensis (27.6 Ma), are supported by reported ranges in other geographic areas, suggesting global rather than regional oceanographic causes. S. martini becomes extinct at the time when sea level is falling (Fig. 2), resulting from a major growth of the East Antarctic ice sheet at 35.9 Ma (Barron et al., 1990). This event does not, however, result in the extinction of $C$. cubensis, which continues on to the late Oligocene Zone P22/N4, where its LO at about 27.6 Ma also corresponds with a sea-level fall.

Among the Neogene species, the first occurrence (FO) of Streptochilus pristinum is uncertain because it is rare and discontinuous in its distribution; however, it appeared by at least $23.9 \mathrm{Ma}$ at Site 807. It is slightly more frequent and more continuous in distribution beginning about $16.5 \mathrm{Ma}$, a time of low sea stand. A prominent seismic reflector is positioned at this stratigraphic level (Mosher and Mayer, this volume), which also corresponds to the Zone N7/N8 boundary as defined by faunal changes that accompanied changing environmental conditions.

The top of the continuous range of $S$. pristinum corresponds with the FO of S. subglobigerum at 10.2 or $10.3 \mathrm{Ma}$. Again, this level corresponds with a low sea stand and a prominent seismic reflector determined at about $10.4 \mathrm{Ma}$ (Mosher and Mayer, this volume). The faunal turnover from $S$. subglobigerum to $S$. latum occurs at $8.1 \mathrm{Ma}$ in Hole $806 \mathrm{~B}$, corresponding with a low sea stand. This event at Site 807 is determined to be at $7.5 \mathrm{Ma}$, a time of rising sea level. On the Eauripik Rise, the event was determined at 8.0 Ma (Resig, 1989), confirming the date at Site 806 and suggesting that the age determined from the sedimentation rate for that part of the Site 807 section is too young.

The faunal turnover from $S$. latum to $S$. globigerum at about 5.2 or 5.3 Ma corresponds with a low sea stand, which abetted the Mediterranean salinity crisis, and a prominent seismic reflector placed at 5.2-5.5 $\mathrm{Ma}$ (Mosher and Mayer, this volume). The extinction of $S$. globigerum, and perhaps a faunal turnover to $S$. globulosum (if the single occurrence at the top of Zone N17 is in error), occurs at about $3.7 \mathrm{Ma}$, just before the first left-to-right coiling change of Pulleniatina. This horizon lies at the beginning of a low sea stand.

In summary, evolution and extinction events of the biserial planktonic foraminifers studied occur in times of low sea level and, presumably, restructuring of the oxygen-minimum habitat in which they lived. At least three of these turnover events correspond with prominent reflectors in the stratigraphic section of the Ontong Java Plateau.

\section{CONCLUSIONS}

Correlations of paleoceanographic events, such as are represented by sea-level curves, with the planktonic response to those events is only as accurate as the scale against which both are measured. The sections studied here were correlated with the time scales of Berggren et al. (1985a, 1985b) using nannofossil and foraminiferal first and last occurrence datums, as determined in shipboard analyses. The resolution of these correlations may be improved in the future through more detailed faunal analysis and through calibrations with the strontium time scale as well as the $\delta^{18} \mathrm{O}$ scale, which denotes more clearly 
variable ice volumes productive of fourth- and fifth-order sea-level changes that might relate to variations on the biserial planktonic foraminifer frequency curve. Nevertheless, the data at hand support the conclusions that follow.

Paleogene and Neogene clustered occurrences of biserial planktonic foraminifers are separated by an interval in the latest Oligocene and early Miocene when low surface-to-bottom thermal gradients existed and amiable climates prevailed. These conditions generally reduced the habitat of the Neogene biserial planktonic foraminifers and other intermediate-dwelling planktonic species that live low in the thermocline in the oxygen-minimum layer.

High frequencies of biserial planktonic foraminifers mostly correspond with high sea stands. High frequencies within low sea stands may reflect fourth- or fifth-order sea-level changes not apparent on the scale employed here. The high frequencies reflect reduced water circulation and better development of the oxygen minimum during periods of high sea level.

Species evolution and extinction events coincide with low sea stands in the Neogene, but they are less well defined in the Paleogene. Presumably, vigorous water circulation resulting in oxygenation leads to species turnover during low sea levels. The increase in continuity of occurrence of $S$. pristinum about $16.5 \mathrm{Ma}$ as well as the FO of $S$. subglobigerum about $10.4 \mathrm{Ma}$ and the turnover of $S$. latum to $S$. globigerum about $5.3 \mathrm{Ma}$ all correspond to prominent seismic reflectors in the Ontong Java Plateau section. At about these levels, the absolute abundance of foraminifers is decreased by an order of magnitude over that in the stratigraphically older or younger section, indicating a reduction in grain size.

The Indo-Pacific ranges of some of the species are well defined and provide useful means of recognizing parts of established biostratigraphic zones. The LO of Streptochilus martini marks the Eocene/Oligocene boundary at $36.6 \mathrm{Ma}$ within Zone P17. The FO of Streptochilus subglobigerum at $10.2-10.4 \mathrm{Ma}$ can aid in the recognition of Zone N15, where it occurs before the FO of Neogloboquadrina acostaensis. The Streptochilus latum FO and S. subglobigerum LO at 7.5-8.1 Ma enable recognition of the upper half of Zone N16. The Streptochilus globigerum FO and S. latum LO at 5.2-5.4 Ma enable recognition of the uppermost part of Subzone N17b, coincident with the Mediterranean salinity crisis. Finally, $S$. globigerum LO and $S$. globulosum FO (continuous occurrence) at 3.6 or $3.7 \mathrm{Ma}$ occurs just before the first left-to-right coiling change of Pulleniatina in the middle of Zone N19/N20.

\section{ACKNOWLEDGMENTS}

The help of Emily Fujiwara, Geetha Wilcoxon, and Garan Ito in preparation of data for this report, as well as research support through a post-cruise grant from the Ocean Drilling Program, is gratefully acknowledged. Review by University of Hawaii School of Earth Science and Technology (SOEST) Editor Diane Henderson improved the manuscript. The two scientific reviewers, Richard Z. Poore of the U.S. Geological Survey, and Steven L. D'Hondt of the University of Rhode Island, were especially helpful in pointing out oversights and inconsistencies in interpretation that I have attempted to rectify. This is SOEST Contribution No. 2968.

\section{REFERENCES}

Barker, P.F., and Burrell, J., 1977. The opening of the Drake Passage. Mar. Geol., 25:15-34.

Barron, J.A., Larsen, B., and Baldauf, J.G., 1990. Extensive late Eocene and early Oligocene Antarctic glaciation and climatic fluctuations during the late Neogene: a synthesis of ODP Leg 119. Geol. Soc. Am. Abstr. Programs, 22:171. (Abstract)

Beckmann, J.P., 1957. Chiloguembelina Loeblich and Tappan and related foraminifera from the lower Tertiary of Trinidad, B.W.I. Bull. U.S. Nat. Mus., 215:83-95.
Berggren, W.A., 1969. Rates of evolution in some Cenozoic planktonic foraminifera. Micropaleontology, 15:351-365.

Berggren, W.A., Kent, D.V., and Flynn, J.J., 1985a. Jurassic to Paleogene: Part 2. Paleogene geochronology and chronostratigraphy. In Snelling, N.J. (Ed.), The Chronology of the Geological Record. Geol. Soc. London Mem., 10:141-195.

Berggren, W.A., Kent, D.V., and Van Couvering, J.A., 1985b. The Neogene: Part 2. Neogene geochronology and chronostratigraphy. In Snelling, N.J. (Ed.), The Chronology of the Geological Record. Geol. Soc. London Mem., 10:211-260.

Berggren, W.A., and Miller, K.G., 1988. Paleogene tropical planktonic foraminiferal biostratigraphy and magnetobiochronology. Micropaleontology, 34:362-380.

Blow, W.H., 1969. Late middle Eocene to Recent planktonic foraminiferal biostratigraphy. In Brönnimann, P., and Renz, H.H. (Eds.), Proc. Ist Int. Conf. Planktonic Microfossils, Geneva: Leiden (E. J. Brill), 1:199-422.

Boersma, A., and Premoli Silva, I., 1983. Paleocene planktonic foraminiferal biogeography and paleoceanography of the Atlantic Ocean. Micropaleontology, 29:355-381.

, 1989. Atlantic Paleogene biserial heterohelicid foraminifera and oxygen minima. Paleoceanography, 4:271-286.

Boersma, A., Premoli Silva, I., and Shackleton, N., 1987. Atlantic Eocene planktonic foraminiferal paleohydrographic indicators and stable isotope paleoceanography. Paleoceanography, 2:287-331.

Boersma, A., Shackleton, N., Hall, M., and Given, Q., 1979. Carbon and oxygen isotope records at DSDP Site 384 (North Atlantic) and some Paleocene paleotemperature and carbon isotope variations in the Atlantic Ocean. In Tucholke, B.E., Vogt, P.R., et al., Init. Repts. DSDP, 43: Washington (U.S. Govt. Printing Office), 695-717.

Brönnimann, P., and Resig, J., 1971. A Neogene globigerinacean biochronologic time-scale of the southwestern Pacific. In Winterer, E.L., Riedel, W.R., et al., Init. Repts. DSDP, 7, Pt. 2: Washington (U.S. Govt. Printing Office), 1235-1469.

De Klasz, I., Kroon, D., and Van Hinte, J.E., 1988. Notes on the foraminiferal genera Laterostomella de Klasz and Rerat and Streptochilus Brönnimann and Resig. In Brummer, G.J.A., and Kroon, D. (Eds.), Planktonic Foraminifers as Tracers of Ocean-climate History: Amsterdam (Free University Press), 163-179.

Eicher, D.L., and Worstell, P., 1970. Cenomanian and Turonian foraminifera from the Great Plains, United States. Micropaleontology, 16:269-324.

Emiliani, C., 1955. Pleistocene temperatures. J. Geol, 63:538-578.

Fisher, A., and Arthur, M., 1977. Secular variations in the pelagic realm. In Cook, H., and Enos, P. (Eds.) Deep Water Carbonate Environments. Spec. Publ.-Soc. Econ. Paleontol. Mineral., 25:19-50.

Fordham, B.G., 1986. Miocene-Pleistocene planktic foraminifers from DSDP Sites 208 and 77, and phylogeny and classification of Cenozoic species. Evol. Monogr., 6:1-200.

Hammond, S.R., Kroenke, L.W., Theyer, F., and Keeling, D.L., 1975. Late Cretaceous and Paleogene paleolatitudes of the Ontong Java Plateau. Nature, 255:46-47.

Haq, B.U., Hardenbol, J., and Vail, P.R., 1987. Chronology of fluctuating sea levels since the Triassic. Science, 235:1156-1167.

Hornibrook, N. de B., 1990. Chiloguembelina cubensis (Palmer) and C. ototara (Finlay), in New Zealand. J. Foraminiferal Res., 20:368-371.

Jenkins, D.G., and Srinivasan, M.S., 1986. Cenozoic planktonic foraminifers from the equatorial to the subantarctic of the southwest Pacific. In Kennett, J.P., von der Borch, C.C., et al., Init. Repts. DSDP, 90: Washington (U.S. Govt. Printing Office), 795-834.

Keigwin, L.D., and Corliss, B.H., 1986. Stable isotopes in late middle Eocene to Oligocene foraminifera. Geol. Soc. Am. Bull., 97:335-345.

Keller, G., 1985. Depth stratification of planktonic foraminifers in the Miocene ocean. Mem. Geol. Soc. Am., 163:177-195.

Keller, G., and Barron, J.A., 1983. Paleoceanographic implications of Miocene deep-sea hiatuses. Geol. Soc. Am. Bull., 94:590-613.

Kennett, J.P., 1982. Marine Geology: Englewood Cliffs, NJ (Prentice Hall).

Kennett, J.P., Keller, G., and Srinivasan, M.S., 1985. Miocene planktonic foraminiferal biogeography and paleoceanographic development of the Indo-Pacific region. Mem.-Geol. Soc. Am., 163:197-236.

Kroenke, L.W., Berger, W.H., Janecek, T.R., et al., 1991, Proc. ODP, Init. Repts., 130: College Station, TX (Ocean Drilling Program).

Lauritzen, R., 1987. Foraminiferal isotopic and assemblage analysis across the Epoch 6 carbon shift, western equatorial Pacific [M.S. thesis]. Univ. of Hawaii. 
Leckie, R.M., 1987. Paleoecology of mid-Cretaceous planktonic foraminifera: a comparison of open ocean and epicontinental sea assemblages. Micropaleontology, 33:164-176.

Loeblich, A., and Tappan, H., 1987. Foraminiferal Genera and Their Classification: New York (Van Nostrand).

Masters, B.A., 1977. Mesozoic planktonic foraminifera. In Ramsay, A.T.S., Oceanic Micropaleontology: London (Academic Press), 301-731.

Miller, K.G., Fairbanks, R.G., and Mountain, G.S., 1987. Tertiary oxygen isotope synthesis, sea level history, and continental margin erosion. Paleoceanography, 2:1-19.

Poore, R., and Gosnell, L., 1985. Apertural features and surface texture of upper Paleocene biserial planktonic foraminifers: links between $\mathrm{Chi}$ loguembelina and Streptochilus. J. Foraminiferal Res., 15:1-5.

Poore, R.Z., and Matthews, R.K., 1984. Oxygen isotope ranking of Late Eocene and Oligocene planktonic foraminifers: implications for Oligocene sea-surface temperatures and global ice volume. Mar. Micropaleontol., 9:111-134.

Resig, J.M., 1989. Stratigraphic distribution of late Neogene species of the planktonic foraminifer Streptochilus in the Indo-Pacific. Micropaleontology, 35:49-62.

Resig, J.M., and Kroopnick, P.M., 1983. Isotopic and distributional evidence of a planktonic habit for the foraminiferal genus Streptochilus Brönnimann and Resig, 1971. Mar. Micropaleontol., 8:235-248.

Shackleton, N.J., and Kennett, J.P., 1975. Paleotemperature history of the Cenozoic and the initiation of Antarctic glaciation: oxygen and carbon isotope analyses in DSDP Sites 277,279, and 281. In Kennett, J.P., Houtz,
R.E., et al., Init. Repts. DSDP, 29: Washington (U.S. Govt. Printing Office), 743-755.

Shackleton, N.J., and Opdyke, N.D., 1973. Oxygen isotope and paleomagnetic stratigraphy of equatorial Pacific Core V28-238: oxygen isotope temperatures and ice volumes on a $10^{5}$ year and $10^{6}$ year scale. Quat. Res., 3:39-55.

1976. Oxygen-isotope and paleomagnetic stratigraphy of Pacific Core V28-239, late Pliocene to latest Pleistocene. Mem.-Geol. Soc. Am. $145: 449-464$.

Takayanagi, Y., and Oda, M., 1976. Shore laboratory report on Cenozoic planktonic foraminifera: Leg 33. In Schlanger, S.O., Jackson, E.D., et al. Init. Repts. DSDP, 33: Washington (U.S. Govt. Printing Office), 451-465.

Thomas, E., 1987. Late Oligocene to Recent benthic foraminifers from Deep Sea Drilling Sites 608 and 610, northeastern North Atlantic. In Ruddimann, W.F., Kidd, R.B., Thomas, E., et al., Init. Repts. DSDP, 94, Pt. 2: Washington (U.S. Govt. Printing Office), 997-1031.

Toumarkine, M., and Luterbacher, H.P., 1985. Paleocene and Eocene planktonic foraminifera. In Bolli, H.M., Saunders, J.B., and Perch-Nielsen, K (Eds.), Plankton Stratigraphy: Cambridge (Cambridge Univ. Press), $87-154$.

Vail, P.R., and Haq, B.U., 1988. Response. Science, 241:599.

Date of initial receipt: 25 November 1991

Date of acceptance: 22 June 1992

Ms 130B-014 


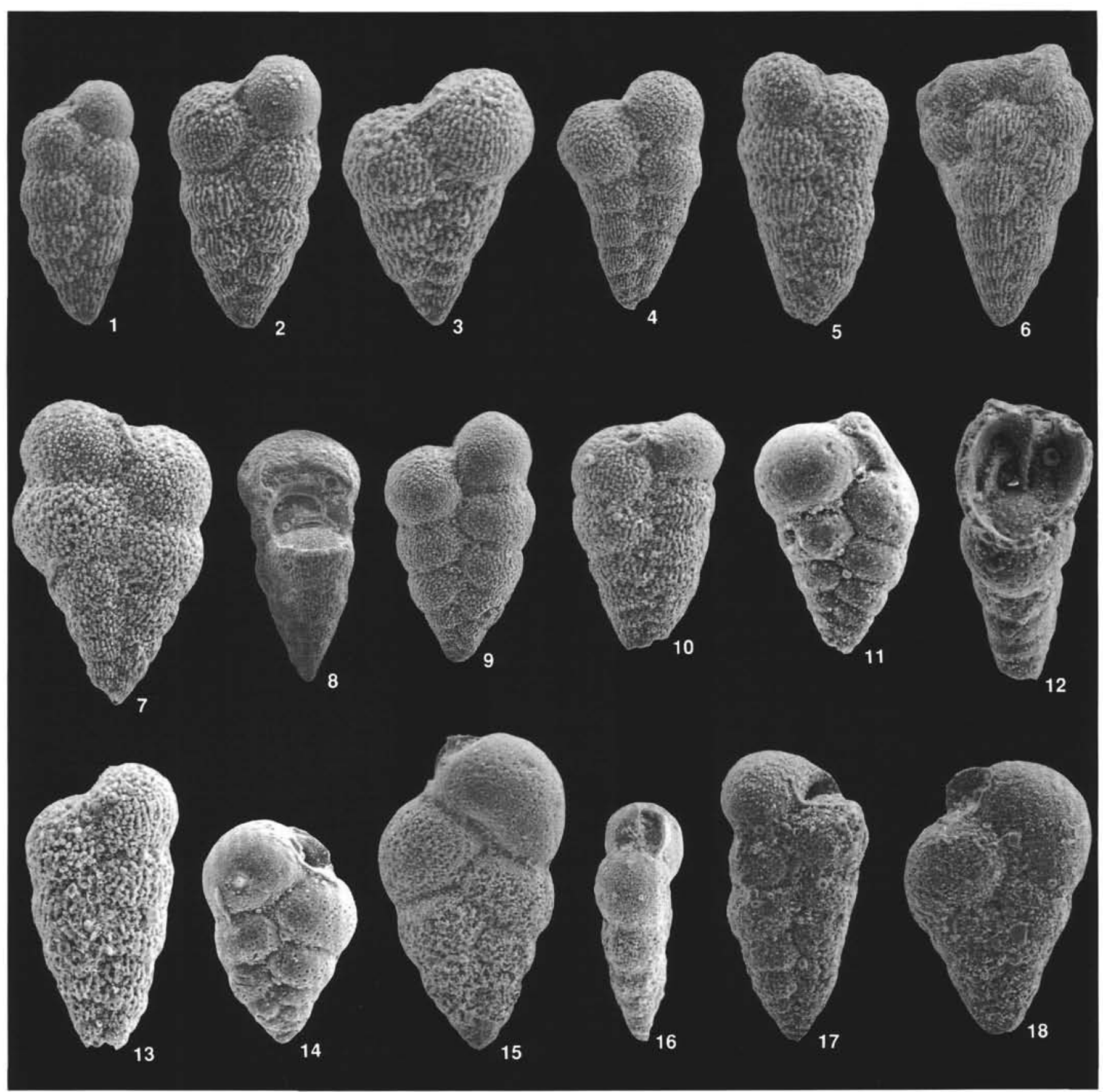

Plate 1. Stratigraphic sequence of Paleogene biserial planktonic foraminifers. 1-8. Lower Oligocene Chiloguembelina cubensis; (1) Sample 130-807A-76X-2, 44-46 cm, 225×, Subzone P21a; (2) Sample 130-807A-78X-4, 44-46 cm, 180x, Subzone P21a; (3) Sample 130-807A-78X-4, 44-46 cm, 225×, Subzone P21a; (4) Sample 130-807C-4R-2, 44-46 cm, 135×, Zone P19; (5) Sample 130-807C-4R-2, 44-46 cm, 225×, Zone P19; (6) Sample 130-807C-4R-2, 44-46 cm, 180×, Zone P19; (7) Sample 130-807C-6R-4, 44-46 cm, 180×, Zone P19; (8) Sample 130-807C-6R-4, 44-46 $\mathrm{cm}, 135 \times$, Zone P19. 9. Chiloguembelina ototara, 125 $\times$, Sample 130-807C-12R-1, 42-44 cm, lower Oligocene, Zone P18. 10. Chiloguembelina cubensis, 180×, Sample 130-807C-12R-1, 42-44 cm, lower Oligocene, Zone P18. 11. Streptochilus martini, 270×, Sample 130-807C-16R-1, 44-46 $\mathrm{cm}$, upper Eocene, Zone P17. 12. Streptochilus martini, 270x, Sample 130-807C-16R-1, 44-46 cm, upper Eocene, Zone P17. 13. Chiloguembelina cubensis, 225×, Sample 130-807C-16R-1, 44-46 cm, upper Eocene, Zone P17. 14. Streptochilus martini, 180×, Sample 130-807C-19R-1, 42-44 cm, upper Eocene, Zone P17. 15. Streptochilus martini, Sample 130-807C-19R-1, 42-44 cm, upper Eocene, Zone P17. 16. Streptochilus martini, 135 $\times$, Sample 130-807C-19R-1, 42-44 cm, upper Eocene, Zone P17. 17. Chiloguembelina cubensis, 180×, Sample 130-807C-19R-1, 42-44 cm, upper Eocene, Zone P17. 18. Streptochilus martini, 180×, Sample 130-807C-26R-1, 35-37 cm, upper Eocene. 